\title{
An NIR-Fluorophore-Based Theranostic for Selective Initiation of Tumor Pyroptosis-Induced Immunotherapy
}

\section{Kewei Wang}

South China University of Technology

\section{Xuan Xiao}

South China University of Technology

\section{Maolin Jiang}

South China University of Technology

Jisi Li

South China University of Technology

Jielian Zhou

South China University of Technology

Youyong Yuan ( $\nabla$ yuanyy@scut.edu.cn )

South China University of Technology

\section{Article}

Keywords: Fluorophore, hemicyanine, pyroptosis, NQ01, immunotherapy

Posted Date: March 10th, 2021

DOl: https://doi.org/10.21203/rs.3.rs-292579/v1

License: (1) This work is licensed under a Creative Commons Attribution 4.0 International License. Read Full License 


\section{An NIR-Fluorophore-Based Theranostic for Selective Initiation of}

\section{Tumor Pyroptosis-Induced Immunotherapy}

3 Kewei Wang, ${ }^{1,2}$ Xuan Xiao, ${ }^{1,2}$ Maolin Jiang, ${ }^{1,2}$ Jisi Li, ${ }^{1,3}$ Jielian Zhou $^{1,4}$ and Youyong Yuan ${ }^{*}, 1,2$

$4 \quad{ }^{1}$ School of Biomedical Sciences and Engineering, Guangzhou International Campus, South China University of Technology, Guangzhou, 511442, P.R. China

$6 \quad{ }^{2}$ National Engineering Research Center for Tissue Restoration and Reconstruction, South China University of Technology, Guangzhou, 510006, P.R. China

$8 \quad{ }^{3}$ Key Laboratory of Biomedical Engineering of Guangdong Province, South China University of Technology, Guangzhou 510006, P.R. China

$10 \quad{ }^{4}$ Key Laboratory of Biomedical Materials and Engineering of the Ministry of Education and 11 Innovation Center for Tissue Restoration and Reconstruction, South China University of Technology, Guangzhou 510006, P. R. China

$14 *$ Address correspondence to: yuanyy@ scut.edu.cn 


\section{Abstract:}

17 Pyroptosis is an inflammatory form of programmed cell death that can effectively eliminate 18 malignant cells and boost anticancer immunity. However, most of the current pyroptosis inducers 19 lack cell selectivity, which may cause severe side effects for cancer therapy. In this work, for the 20 first time, we discovered that the commonly used near-infrared (NIR) fluorogenic hemicyanine $21\left(\mathrm{CyNH}_{2}\right)$ induces pyrolysis to kill cancer cells and boost antitumor immunity. Cancer cells 22 overexpressing the $\mathrm{NAD}(\mathrm{P}) \mathrm{H}$ : quinone oxidoreductase isozyme 1 (NQO1)-responsive theranostic $23\left(\mathrm{NCyNH}_{2}\right)$ were designed for selective cell pyroptosis and were nonfluorescent with low toxicity 24 before activation. In the presence of NQO1, the fluorescence of $\mathrm{CyNH}_{2}$ was restored and could 25 selectively initiate pyroptosis of cancer cells and further lead to systemic antitumor immunity 26 activation for solid tumor therapy. Thus, this fluorogenic NIR dye may represent a novel theranostic 27 agent for the selective initiation of tumor pyroptosis.

29 KEYWORDS: Fluorophore, hemicyanine, pyroptosis, NQO1, immunotherapy 


\section{Introduction}

An important therapeutic method to kill cancer cells is programmed cell death (PCD), which primarily includes autophagy, apoptosis, pyroptosis and ferroptosis ${ }^{1-3}$. Pyroptosis is a unique form of PCD characterized by DNA fragmentation, chromatin condensation, cellular swelling with large bubbles and cell content leakage and has been shown to be related to malignant tumors and inflammatory diseases ${ }^{4-9}$. Pyroptosis critically depends on the formation of plasma membrane pores by members of the gasdermin protein family, often (but not always) as a consequence of inflammatory caspase activation. After caspase cleavage, the gasdermin protein family (GSDMA, GSDMB, GSDMC, GSDMD and GSDME) releases gasdermin-N domains that combine with membrane phospholipids and perforate the cell membrane with a pore size of $\sim 18 \mathrm{~nm}$, disrupting osmotic potential and leading to cell swelling and large bubbles ${ }^{10-12}$.

Compared to apoptosis, pyroptosis may represent a more relevant pathway for cancer therapy due to its ability to prime antitumor immune responses. Immunotherapies using the patient's own immune system to specifically recognize and kill tumor cells have been very successful in the clinic and have the potential to cure cancer ${ }^{13,14}$. Tumors that are highly immunogenic (hot) are key to effective immunotherapy ${ }^{15}$. Unfortunately, most human tumors are immunogenically cold and lack tumor-infiltrating lymphocytes, which limits the success of current immunotherapy strategies ${ }^{16}$. Recent studies have shown that inducing tumor cell pyrolysis improves the immune microenvironment in solid tumors, which induces tumor regression to increase $\mathrm{CD} 4^{+} \mathrm{T}$ helper cells, cytotoxic T cells and natural killer cells and decreases the percentage of T regulatory cells ${ }^{17}$. Cell pyroptosis is characterized by cell membrane rupture, and many proinflammatory cytokines and antigens of tumor cells are released into the extracellular environment through pores, which activate the immune system and lead to inflammation ${ }^{18-20}$. Based on these findings, intense inflammation

4 induced by proinflammatory cytokines and activation of antigen-specific $\mathrm{T}$ cells presented with antigens can cause powerful immune responses ${ }^{21,22}$. In addition, the pyroptosis-induced 
56 inflammatory microenvironment in tumors enhances effective lymphocyte infiltration, and 57 activation can improve the response rate of checkpoint blockade in inducing antitumor immunity $58 \quad 17$. Therefore, the initiation of pyroptosis death through various strategies brings new opportunities 59 for cancer therapy.

60 Several studies have shown that certain molecules, chemotherapeutic drugs or ions, such as 61 iron ${ }^{23,24}, \mathrm{NaCl}$ nanoparticles ${ }^{25}, \mathrm{Na}_{2} \mathrm{~S}_{2} \mathrm{O}_{8}$ nanoparticles ${ }^{26}$, metformin ${ }^{27}$, and glucose oxidase (GOD) $62{ }^{28}$, induce cell pyroptosis in a GSDMD/GSDME-mediated manner. In addition, Liu et al. designed 63 a series of membrane anchoring photosensitizers (TBD-R PSs) that produce cytotoxic ROS in situ 64 can induce cell pyroptosis upon light irradiation. ${ }^{29}$ Pretreatment of cancer cells with decitabine to 65 reverse GSDME silencing and in combination with the chemotherapeutic drug cisplatin also 66 triggers pyroptosis for tumor immunotherapy ${ }^{30}$. Although pyroptosis has been extensively studied 67 in various inflammatory diseases in recent years, its application in cancer therapy is still in early stages, not to mention selectively initiating pyroptosis in cancer cells.

Recent development of cancer theranostics that integrate the function of imaging and therapy has allowed real-time monitoring of drug distribution, assessment of therapeutic outcomes, and individualized selection of treatment modalities, which holds great promise for personalized medicine ${ }^{31}$. Herein, for the first time, we discovered that an amino $\left(-\mathrm{NH}_{2}\right)$-containing hemicyanine (Cy) fluorophore (denoted as $\mathrm{CyNH}_{2}$ ) has the potential to induce pyrolysis to kill tumor cells. We demonstrated that $\mathrm{CyNH}_{2}$ selectively accumulates within energized mitochondria, which causes mitochondrial membrane damage, leading to cytochrome $\mathrm{c}(\mathrm{Cyt} \mathrm{c})$ release into the cytoplasm and activating caspase-3. Then, activated caspase-3 cleaves GSDME, generating a GSDME-N fragment that perforates membranes and induces pyroptosis. To improve the tumor selectivity of $\mathrm{CyNH}_{2}$, an NQO1-responsive $\mathrm{CyNH}_{2}$ (denoted as $\mathrm{NCyNH}_{2}$ ) was designed because NQO1 is overexpressed by up to 100 -fold in different cancer cells ${ }^{32}$. Before activation, fluorescence of $\mathrm{CyNH}_{2}$ is in the off state due to the intramolecular charge transfer (ICT) of $\mathrm{CyNH}_{2}$. More importantly, the cytotoxicity 
of $\mathrm{NCyNH}_{2}$ is low. Upon encountering overexpressed intracellular NQO1 in cancer cells, the NIR

fluorescent signal of $\mathrm{CyNH}_{2}$ is turned on, and the synchronous cytotoxicity of $\mathrm{CyNH}_{2}$ is restored to initiate selective pyroptosis in cancer cells. In addition, cancer cell pyroptosis induced by $\mathrm{NCyNH}_{2}$ induces systemic antitumor immunity for tumor therapy. Furthermore, $\mathrm{NCyNH}_{2}$ was encapsulated in the Food and Drug Administration (FDA)-approved amphiphilic polymer poly(ethylene glycol)-block-poly(lactic-co-glycolic acid) (PEG- $b$-PLGA) as a nanocarrier for systemic administration and combined with the immune checkpoint inhibitor $\alpha$ PD- 1 to effectively inhibit tumor growth and prolong survival in mice. Furthermore, combination therapy could induce powerful memory efficacy to prevent tumor recurrence, suggesting the potential of NIR fluorophore-based $\mathrm{CyNH}_{2}$ for selective initiation of tumor pyroptosis-induced immunotherapy.

\section{Results and discussion}

The synthesis of $\mathrm{CyNH}_{2}$ is shown in Scheme $\mathrm{S} 1$. Compound $\mathbf{1}$ was synthesized by an $\mathrm{N}$ alkylation reaction of trimethylindolenine and iodoethane. Compound $\mathbf{2}$ was synthesized by a VilsmeierHaack reaction of phosphorus oxychloride and cyclohexanone. In the presence of sodium acetate, compound 3 was synthesized through a condensation reaction. $\mathrm{CyNH}_{2}$ was synthesized through a nucleophilic substitute reaction of compound $\mathbf{3}$ and 3-nitrophenol in the presence of triethylamine, followed by nitro reduction and cyclization in the presence of $\mathrm{SnCl}_{2}$ and concentrated $\mathrm{HCl}$. The purified products were characterized by NMR spectroscopy to confirm their structures (Fig. S1-S6 in the Supporting Information). The chemical structure and photophysical properties of $\mathrm{CyNH}_{2}$ are shown in Fig. 1A, which shows an absorption maximum at $670 \mathrm{~nm}$ and an emission maximum at $730 \mathrm{~nm}$, indicating that $\mathrm{CyNH}_{2}$ has the potential to be an NIR dye for fluorescence imaging.

The mechanism of $\mathrm{CyNH}_{2}$-induced cell pyrolysis. We used flow cytometry analysis and confocal imaging to evaluate the internalization of $\mathrm{CyNH}_{2}$ by mouse breast cancer cells (4T1) and mouse colon cancer cells (CT26). As shown in Fig. S7, we observed a time-dependent increase in 
intracellular fluorescence signals of $\mathrm{CyNH}_{2}$, indicating that $\mathrm{CyNH}_{2}$ can be efficiently taken up by

107 cells and can be used as an NIR dye for fluorescence imaging. Intracellular localization of $\mathrm{CyNH}_{2}$

108 in 4T1 or CT26 cells was further studied using confocal microscopy. Cells were exposed to $\mathrm{CyNH}_{2}$

$109\left(1 \mu \mathrm{g} \mathrm{mL}^{-1}\right)$ for $4 \mathrm{~h}$ and costained with MitoTracker Green. As shown in Fig. $1 \mathrm{~B}$ and Fig. S8, CyNH

110 (red fluorescence) overlapped well with MitoTracker (green fluorescence). Quantification of the

111 fluorescence overlaps of $\mathrm{CyNH}_{2}$ and MitoTracker by Pearson correlation coefficients was

112 calculated to be 0.81 . These results indicate that $\mathrm{CyNH}_{2}$ exhibits selective mitochondrial

113 localization in 4T1 and CT26 cells.

114 To evaluate the effect of $\mathrm{CyNH}_{2}$ on mitochondrial function, the MitoProbe ${ }^{\mathrm{TM}} \mathrm{JC}-1$ Assay Kit

115 was used to detect changes in mitochondrial membrane potential in 4T1 cells after exposure to

$116 \mathrm{CyNH}_{2}$ at different concentrations. As shown in Fig. S9A, cells without any treatments showed

117 bright-red fluorescence, while the red fluorescence in cells treated with $\mathrm{CyNH}_{2}$ was significantly

118 decreased, and green fluorescence was significantly increased. These results indicate that $\mathrm{CyNH}_{2}$

119 depolarizes the mitochondrial membrane potential in 4T1 cells, which was further quantitatively

120 confirmed by flow cytometry analysis. As shown in Fig. 1C and S9B, compared to the high red

121 fluorescence intensity and low green fluorescence intensity of PBS-treated cells, $\mathrm{CyNH}_{2}$-treated

122 cells showed a concentration-dependent decrease in red fluorescence intensity and an increase in

123 green fluorescence intensity. These results indicate that $\mathrm{CyNH}_{2}$ at low concentrations of $1 \mu \mathrm{g} \mathrm{mL}^{-1}$

124 decreases mitochondrial membrane potential and damages the mitochondrial membrane.

$125 \mathrm{CyNH}_{2}$ aggregation in mitochondria causes mitochondrial membrane damage, which leads to

mitochondrial dysfunction. As shown in Fig. S10A-S10C, the mitochondrial oxygen consumption rate (OCR) and mitochondrial respiration rate (MRR) were reduced by $53.2 \%$ and $89.6 \%$, respectively, after cells were pretreated with $6 \mu \mathrm{gLL}^{-1} \mathrm{CyNH}_{2}$ for $8 \mathrm{~h}$. The decreased OCR and MRR in turn affect adenosine triphosphate (ATP) and reactive oxygen species production at complexes I and III of the mitochondrial respiratory chain ${ }^{10}$. Levels of intracellular ROS after 
treatment with different concentrations of $\mathrm{CyNH}_{2}$ were evaluated using the cell-permeable ROS sensor 2',7'-dichlorofluorescin diacetate (DCFH-DA). As shown in Fig. S11, cells treated with $\mathrm{CyNH}_{2}$ exhibited bright green fluorescence, demonstrating increased ROS generation in 4T1 cells.

Flow cytometry was used to quantify ROS levels, which showed that $\mathrm{CyNH}_{2}$ at a concentration of $1 \mu \mathrm{g} \mathrm{mL} \mathrm{m}^{-1}$ was sufficient to maximize ROS generation (Fig. 1D). A firefly luciferase-based ATP assay kit was used to measure intracellular ATP levels. As shown in Fig. 1E, 4T1 cells treated with $\mathrm{CyNH}_{2}$ showed a concentration-dependent decrease in levels of intracellular ATP. Relative intracellular ATP levels in 4T1 cells treated with $4 \mu \mathrm{g} \mathrm{mL}^{-1} \mathrm{CyNH}_{2}$ decreased to $13.2 \%$ of that in PBS-treated cells.

To confirm that $\mathrm{CyNH}_{2}$ induces pyrolysis, we first observed the morphological changes in 4T1 cells after treatment with different concentrations of $\mathrm{CyNH}_{2}$. We observed that $4 \mathrm{~T} 1$ cells clearly exhibited pyroptosis with cell swelling and large bubbles on the plasma membrane in response to $\mathrm{CyNH}_{2}$ treatment (Fig. 1F). Next, the leakage of lactate dehydrogenase (LDH) in the cell supernatant was examined. As shown in Fig. 1G, 4T1 cells showed a concentration-dependent release of $\mathrm{LDH}$ upon incubation with $\mathrm{CyNH}_{2}$. Considering that $\mathrm{Cyt} \mathrm{c}$ is a heme protein anchored to the inner membrane of mitochondria, when $\mathrm{CyNH}_{2}$ aggregates in mitochondria, it causes mitochondrial membrane damage, Cyt $\mathrm{c}$ release into the cytoplasm and activates caspase-3. Thus, Cyt c levels in the cytoplasm and caspase-3 activity in 4T1 cells were analyzed after treatment with different concentrations of $\mathrm{CyNH}_{2}$. As shown in Fig. $1 \mathrm{H}$, the green fluorescence signal of Cyt c aggregates in untreated cells, but after treatment with different concentrations of $\mathrm{CyNH}_{2}$, the fluorescence signal of Cyt c began to diffuse. When cells were exposed to $8 \mu \mathrm{gLL}^{-1} \mathrm{CyNH}_{2}$ for 8 $\mathrm{h}$, the green fluorescent signal was distributed throughout the cells. These results confirmed that cells treated with $\mathrm{CyNH}_{2}$ induce Cyt c release into the cytoplasm. Next, intracellular caspase-3 activity in 4T1 cells treated with different concentrations of $\mathrm{CyNH}_{2}$ was studied. Intracellular caspase-3 activity (Fig. 1I) exhibited a concentration-dependent increase. Compared to the negative 
control, intracellular caspase-3 activity increased by 13.84 -fold in response to treatment with $10 \mu \mathrm{g}$ $\mathrm{mL}^{-1} \mathrm{CyNH}_{2}$ for $8 \mathrm{~h}$. Recent studies claim that chemotherapeutic drug-induced activation of caspase-3 cleaves GSDME to produce a GSDME-N fragment that perforates membranes and induces pyroptosis ${ }^{33}$. To further confirm $\mathrm{CyNH}_{2}$-induced pyroptosis, intracellular levels of GSDME-FL and GSDME-N were detected by western blotting analysis. As shown in Fig. 1J and Fig. S12, GSDME-N was observed in $\mathrm{CyNH}_{2}$-treated cells at high levels. Additionally, cells treated with $\mathrm{CyNH}_{2}$ were stained with propidium iodide (PI) and annexin V-FITC to analyze apoptosis and necrosis. As shown in Fig. 1K and Fig. S13, compared to untreated cells, the percentages of necrotic cells significantly increased with increasing concentrations of $\mathrm{CyNH}_{2}$ for $12 \mathrm{~h}$. In summary, we conclude that when $\mathrm{CyNH}_{2}$ aggregation in mitochondria causes mitochondrial membrane damage, Cyt $\mathrm{c}$ is released into the cytoplasm and activates caspase-3, which cleaves GSDME, generating a GSDME-N fragment that perforates membranes and finally induces pyroptosis (Fig. 1L).

We next examined the cytotoxicity of $\mathrm{CyNH}_{2}$ in different cell lines. As shown in Fig. S14, the cancer cell lines 4T1 and CT26, human lung adenocarcinoma (A549), human cervical cancer cells (HeLa), human breast cancer cells (MCF-7), mouse melanoma cells (B16), and mouse pancreatic cancer (Panco2)) were effectively killed by $\mathrm{CyNH}_{2}$, with half maximal inhibitory concentration ( $\mathrm{IC}_{50}$ ) values ranging from 1.91 to $9.58 \mu \mathrm{M}$. The live/dead assay (Fig. S15) was consistent with the cytotoxicity study. Normal cells, such as mouse embryonic fibroblasts (MEFs), human embryonic kidney cells (293T) and human umbilical vein endothelial cells (HUVECs), were also killed by $\mathrm{CyNH}_{2}$ with $\mathrm{IC}_{50}$ values of $3.08,1.86$ and $3.19 \mu \mathrm{M}$, respectively. The high toxicity and poor cell selectivity seriously hampers the application of $\mathrm{CyNH}_{2}$ in cancer treatment.

Tumor cell selectivity of NCyNH2. In recent decades, chemotherapy use has been severely restricted due to the severe side effects caused by high toxicity and poor tumor selectivity. To improve the tumor selectivity of chemotherapy and selectively release anticancer drugs in response to stimuli in tumor microenvironments, such as enzymes, $\mathrm{pH}$, ROS, etc., extensive efforts have 
been devoted to developing stimuli-responsive prodrugs ${ }^{34}$. Since enzymatic reactions are selective,

182 effective, and involved in all physiological, metabolic, and pathological processes, they have been

183 increasingly used as a trigger for responsive nanostructures. Extensive studies have shown that 184 NQO1 is upregulated up to 100 -fold in pancreatic, breast, lung, cervical, and colorectal cancers ${ }^{35}$.

185 Thus, an NQO1-responsive $\mathrm{CyNH}_{2}$ theranostic (denoted as $\mathrm{NCyNH}_{2}$ ) was designed and synthesized according to Scheme S2 and characterized in Fig. S16-S18.

$\mathrm{NCyNH}_{2}$ is initially weakly fluorescent, as $\mathrm{CyNH}_{2}$ is in a caged state with diminished electrondonating capacity of the nitrogen atoms ${ }^{36}$. In this state, the toxicity of $\mathrm{NCyNH}_{2}$ is also low. The fluorescence and cytotoxicity of $\mathrm{CyNH}_{2}$ is recovered when $\mathrm{NCyNH}_{2}$ is degraded by NQO1 to release free $\mathrm{CyNH}_{2}$ (Fig. 2A). We first studied the fluorescence change in $\mathrm{NCyNH}_{2}\left(2 \mu \mathrm{g} \mathrm{mL} \mathrm{m}^{-1}\right)$ after incubation with NQO1 $\left(40 \mu \mathrm{g} \mathrm{mL}^{-1}\right)$ at different time points. The fluorescence intensity of $\mathrm{NCyNH}_{2}$ (Fig. 2B) significantly increased with incubation time, indicating that $\mathrm{CyNH}_{2}$ is released in free form from $\mathrm{NCyNH}_{2}$ upon incubation with NQO1. Then, the intracellular fluorescence of $\mathrm{CyNH}_{2}$ was studied by incubating $\mathrm{NCyNH}_{2}\left(1 \mu \mathrm{g} \mathrm{mL} \mathrm{m}^{-1}\right)$ with $4 \mathrm{~T} 1$ cells and MEFs. Cells were incubated with $\mathrm{NCyNH}_{2}$ or $\mathrm{CyNH}_{2}\left(1 \mu \mathrm{g} \mathrm{mL}^{-1}\right)$ for $4 \mathrm{~h}$ and further incubated for $12 \mathrm{~h}$ before being observed by CLSM. For some of the groups, cells were pretreated with an NQO1 inhibitor (dicoumarol (DIC), $50 \mu \mathrm{M}$ ) for $1 \mathrm{~h}$ to inhibit intracellular NQO1 activity. As shown in Fig. 2C, cells coincubated with $\mathrm{CyNH}_{2}$ showed a strong red fluorescence signal with or without NQO1 inhibitor pretreatment. In contrast, cells coincubated with $\mathrm{NCyNH}_{2}$ showed a strong red fluorescence signal, while cells pretreated with the NQO1 inhibitor showed a very weak fluorescence signal. MEFs with low NQO1 levels were incubated for an additional $20 \mathrm{~h}$ after $4 \mathrm{~h}$ of coincubation with $\mathrm{NCyNH}_{2}$ or $\mathrm{CyNH}_{2}\left(1 \mu \mathrm{g} \mathrm{mL} \mathrm{L}^{-1}\right)$. Only cells coincubated with $\mathrm{CyNH}_{2}$ showed a strong red fluorescence signal, while cells treated with $\mathrm{NCyNH}_{2}$ exhibited a diminished fluorescence signal. These results indicate that $\mathrm{NCyNH}_{2}$ has good selectivity for tumor cells overexpressing NQO1. 
To further confirm whether $\mathrm{NCyNH}_{2}$ induces pyroptosis, the morphology of 4T1 cells after treatment with $\mathrm{NCyNH}_{2}$ was observed by confocal microscopy. We observed that 4T1 cells clearly presented cell membrane ballooning after treatment with $\mathrm{NCyNH}_{2}$ (Fig. 2D). However, pyroptotic cells were significantly reduced when intracellular NQO1 activity was inhibited by the NQO1 inhibitor in the $\mathrm{NCyNH}_{2}$ group, while the inhibitor had no effect on cells treated with $\mathrm{CyNH}_{2}$. These cells were further stained with propidium iodide (PI) and annexin V-FITC to analyze apoptosis and necrosis. As presented in Fig. S19, the percentages of necrotic cells were significantly reduced when intracellular NQO1 activity was inhibited by the NQO1 inhibitor in the NCyNH2 group, while there were no differences in cells treated with $\mathrm{CyNH}_{2}$. The cell morphology changes of MEFs after treatment with $\mathrm{CyNH}_{2}$ or $\mathrm{NCyNH}_{2}$ were also studied, and the results are shown in Fig. 2E. Most of the cells clearly showed membrane ballooning after $\mathrm{CyNH}_{2}$ treatment, while cells treated with $\mathrm{NCyNH}_{2}$ showed little pyroptosis. These results indicate that $\mathrm{NCyNH}_{2}$ has good selectivity to induce pyroptosis in cancer cells overexpressing NQO1. To further confirm this phenomenon, the cytotoxicity of $\mathrm{NCyNH}_{2}$ to different cell lines was examined. As shown in Fig. S20 and Fig. 2F, cancer cells (4T1, CT26, A549, HeLa, MCF-7, B16, Panco2) were effectively killed by $\mathrm{NCyNH}_{2}$, with $\mathrm{IC}_{50}(48 \mathrm{~h})$ values between 3.21 and $10.4 \mu \mathrm{M}$, which is comparable to $\mathrm{CyNH}_{2}$. In contrast, the $\mathrm{IC}_{50}(48 \mathrm{~h})$ values of $\mathrm{NCyNH}_{2}$ for MEFs, 293T cells and HUVECs increased 4.3-fold, 7.8-fold and 5.4-fold compared to that of $\mathrm{CyNH}_{2}$. These results confirm that $\mathrm{NCyNH}_{2}$ has high selectivity for cancer cells overexpressing NQO1.

Mature mouse bone marrow-derived dendritic cells (BMDCs) and in vivo prophylactic

tumor vaccination study. Recent studies have demonstrated that tumor cell pyroptosis can boost antitumor immunity ${ }^{17}$. To further verify whether $\mathrm{NCyNH}_{2}$-induced tumor cell pyrolysis initiates antitumor immunity, ATP and high mobility group box 1 (HMGB1) were monitored in the cell supernatant after treatment with different concentrations of $\mathrm{NCyNH}_{2}$. Fig. 3A shows that HMGB1 was primarily localized in the nucleus of $4 \mathrm{~T} 1$ cells without any treatments and that treatment with 
$\mathrm{NCyNH}_{2}$ induced HMGB1 release from the nucleus. The concentration of HMGB1 in the 232 supernatant of cells treated with $\mathrm{NCyNH}_{2}$ was analyzed though enzyme-linked immune sorbent 233 assay (ELISA). As shown in Fig. 3B, a large amount of HMGB 1 was released from the nucleus of 234 4T1 cells after treatment with $\mathrm{NCyNH}_{2}$. Moreover, 4T1 cells treated with $\mathrm{NCyNH}_{2}$ exhibited 235 increased ATP secretion (Fig. 3C). Furthermore, we investigated $\mathrm{NCyNH}_{2}$-induced antitumor 236 immunity by testing DC maturation. Bone marrow-derived dendritic cells (BMDCs) were separated 237 from BALB/c mice and incubated with 4T1 cells pretreated with different concentrations of $238 \mathrm{NCyNH}_{2}$ (Fig. 3D). Upregulated levels of costimulatory molecules, such as CD80 and CD86, were detected to evaluate DC maturation in vitro. As shown in Fig. $3 \mathrm{E}$ and $3 \mathrm{~F}$, the results showed negligible DC maturation after incubation with untreated 4T1 cells for $24 \mathrm{~h}$ because the tumor cells had low immunogenicity. The frequency of mature DCs significantly increased when DCs were incubated with $\mathrm{NCyNH}_{2}$-pretreated 4T1 cells. 4T1 cells pretreated with $\mathrm{NCyNH}_{2}\left(6 \mu \mathrm{g} \mathrm{mL} \mathrm{mL}^{-1}\right)$ exhibited a 3.1-fold higher DC maturation rate (approximately 58.6\%) than cells without any treatments. These results indicate that tumor cell pyroptosis induced by $\mathrm{NCyNH}_{2}$ has high immunogenicity.

Furthermore, in vivo vaccination was performed to verify whether $\mathrm{NCyNH}_{2}$-induced tumor cell pyrolysis induced antitumor immunity. 4T1 tumor cells pretreated with $\mathrm{NCyNH}_{2}$ were subcutaneously injected into the left armpit of male BALB/c mice at 0 and $7 \mathrm{~d}$, and mice were injected with 4T1 cells without any treatment into the contralateral flank 14 days after immunization (Fig. 3G). Doxorubicin (DOX), a typical chemodrug that induces immunogenic death of tumor cells and causes antitumor immunity, was used as a positive control ${ }^{37}$. As shown in Fig. $3 \mathrm{H}$, the effect of vaccination with PBS-treated cells on contralateral tumor growth was negligible, while both DOX- and $\mathrm{CyNH}_{2}$-treated cells prevented (or delayed) challenged tumor growth. It is worth noting that through the end of the study (17 days), 5 of 6 mice in the $\mathrm{NCyNH}_{2}$-treated group were tumor- 
free. These results indicate that $4 \mathrm{~T} 1$ cell death induced by $\mathrm{NCyNH}_{2}$ boosts antitumor immunity to

prevent tumorigenesis.

regional radiotherapy, photodynamic therapy and photothermal therapy, can induce immunogenic

cell death to activate antitumor immunity and thereby inhibit the growth of distant tumors, which

is known as the "abscopal effect" $38-41$. We further studied whether localized administration of $\mathrm{NCyNH}_{2}$ also elicits an "abscopal effect" through a bilateral subcutaneous tumor model. DOX induces immunogenic death of cancer cells and activates immune systems to inhibit the growth of distant tumors and was used as a positive control ${ }^{42}$. In this respect, we established a bilateral subcutaneous tumor model in immunocompetent mice whose left (termed "local tumor") and right (termed "distant tumor") second breast pads were subcutaneously inoculated with 4T1 cells. When the local tumor reached approximately $100 \mathrm{~mm}^{3}$, therapeutic agents were injected into this tumor four times, while the distant tumor was deliberately left untreated (Fig. 4A). As shown in Fig. 4B, little body weight change occurred during the treatments, indicating negligible side effects. Tumor volume growth curves are shown in Fig. 4C. Compared to the PBS group, the tumor volumes of both local and distant tumors exhibited a slight increase after treatment with $\mathrm{NCyNH}_{2}$ or DOX. The tumor weight and corresponding tumor images are shown in Fig. 4D and 4E, which were consistent with the tumor inhibition results. To further evaluate the therapeutic effect in vivo, histological analysis by hematoxylin and eosin (H\&E) staining, apoptosis detection by terminal deoxynucleotidyl transferase dUTP nick-end labeling (TUNEL) staining and cell proliferation activity detection by Ki67 staining of tumor sections were performed, and results are shown in Fig. S21A. The results clearly demonstrated that tumors treated with DOX or $\mathrm{NCyNH}_{2}$ presented severe fragmentation and nuclear shrinkage in the tumor area, decreased tumor cell proliferation and an increased percentage of tumor cell apoptosis, consistent with the results of the therapeutic study. At the end of treatment, the lungs of all mice after different treatments were collected and analyzed 
by H\&E staining. H\&E staining of lung tissue is shown in Fig. S21B. The mice treated with PBS

showed obvious lung metastasis, while mice treated with $\mathrm{NCyNH}_{2}$ or $\mathrm{DOX}$ showed little or no lung metastases. These results indicate that localized delivery of $\mathrm{NCyNH}_{2}$ effectively suppresses the growth of local and distant tumors and inhibits tumor metastasis, confirming that localized treatments with $\mathrm{NCyNH}_{2}$ elicit abscopal antitumor effects. Next, we studied whether local and distant tumor growth- and metastasis-related inhibition is attributable to enhanced antitumor immunity. $\mathrm{CD}^{+}$cytotoxic $\mathrm{T}$ lymphocytes (CTLs) actively eliminate tumor cells after being activated by DCs presenting tumor antigens, which play the most important role in the antitumor immune response ${ }^{43}$, while regulatory T cells (Tregs) interfere with effector T cells and DC function to suppress antitumor immunity ${ }^{44}$. $\mathrm{CD} 11 \mathrm{c}^{+}$differentiation was detected to evaluate levels of infiltrating DCs in primary tumors in response to different treatments. As shown in Fig. S22A and $\mathrm{B}$, the presence of DCs $\left(\mathrm{CD} 45^{+} \mathrm{CD} 11 \mathrm{c}^{+}\right)$in tumor tissues was significantly increased after treatment with $\mathrm{NCyNH}_{2}$ or DOX, and the percentage of mature DCs $\left(\mathrm{CD} 45^{+} \mathrm{CD} 11 \mathrm{c}^{+} \mathrm{CD} 80^{+}, \mathrm{Fig}\right.$. S22C and D) was high in the primary tumor, indicating that this treatment significantly promoted tumor antigen presentation. Flow cytometry analysis revealed a significantly increased presence of CTLs $\left(\mathrm{CD} 45^{+} \mathrm{CD}^{+} \mathrm{CD}^{+}\right)$and decreased Tregs $\left(\mathrm{CD} 45^{+} \mathrm{CD}^{+} \mathrm{CD}^{+} \mathrm{Foxp}^{+}\right)$in both local and distant tumors within the tumor microenvironment after treatment with $\mathrm{NCyNH}_{2}$ and $\mathrm{DOX}$ (Fig. 4A-4D). These results indicate that $\mathrm{NCyNH}_{2}$ represents a good strategy to induce selective tumor cell pyroptosis and boost the antitumor immune response. Tumor draining lymph nodes (TDLNs) are key sites where mature DCs present captured antigens to $\mathrm{T}$ cells for functionally priming $\mathrm{CD}^{+} \mathrm{T}$ cells towards antitumor immunity ${ }^{45}$. CTLs in TDLNs were also analyzed. As shown in Fig. S23A23B, the percentage of CTLs in TDLNs significantly increased. TNF- $\alpha$ and IFN- $\gamma$ in the serum after different treatments were quantitatively detected by ELISA. Mice treated with DOX or $\mathrm{NCyNH}_{2}$ exhibited significantly elevated concentrations of TNF- $\alpha$ (Fig. 4J) and IFN- $\gamma$ (Fig. 4K) compared to those treated with PBS, indicating that treatment caused a stronger antitumor immune response. 
These results demonstrate that tumor cell pyroptosis induced by $\mathrm{NCyNH}_{2}$ induces strong antitumor immunity.

Preparation and characterization of $\mathbf{N C y N P}$. Although $\mathrm{NCyNH}_{2}$ has a satisfactory therapeutic effect, poor water solubility hinders its systemic delivery. In this case, we selected the FDA-approved amphiphilic polymer $\mathrm{PEG}_{5 \mathrm{k}}-b$ - $\mathrm{PLGA}_{8 \mathrm{k}}$ to encapsulate $\mathrm{NCyNH}_{2}$, and the obtained nanoparticles were denoted NCyNP. As shown in Fig. S24, the average hydrodynamic particle size of NCyNPs was approximately $150 \mathrm{~nm}$. The loading ratio of $\mathrm{NCyNH}_{2}$ was calculated as $6 \%$ according to the standard curve of $\mathrm{NCyNH}_{2}$. Confocal images in Fig. S25A show that $\mathrm{CyNH}_{2}$ can also be released and activated in tumor cells overexpressing NQO1. As shown in Fig. S25B, we observed that $4 \mathrm{~T} 1$ cells clearly presented cell membrane ballooning after treatment with NCyNP. The cytotoxicity test demonstrated that NCyNP elicited higher cytotoxicity in tumor cells than in normal cells, as shown in Fig. S25C. These results indicate that NCyNP also has good selectivity for tumor cells overexpressing NQO1. Encouraged by these promising imaging results in vitro, we further examined the feasibility of NCyNP as an in vivo NIR fluorescence-tracked prodrug activation system utilizing the NIR $\mathrm{CyNH}_{2}$ channel. The results are shown in Fig. S26A. NIR fluorescence was clearly observable $4 \mathrm{~h}$ after intravenous injection, and fluorescence intensity gradually increased over time. When NQO1 activity in the tumor microenvironment was inhibited by intratumoral injection of DIC, the NIR fluorescence intensity significantly weakened, indicating that less $\mathrm{CyNH}_{2}$ was released from NCyNPs. The tumors and major organs were collected from mice for ex vivo imaging $36 \mathrm{~h}$ after intravenous injection, as shown in Fig. S26B, and quantitative analysis of the NIR fluorescence intensity is shown in Fig. S26C. The results clearly show that the fluorescence intensity in tumors is significantly higher than in non-tumor tissues, indicating that NCyNPs have good selectivity for tumors. These results suggest that NCyNPs can be used as theranostics to allow real-time monitoring of drug activation, which holds great promise for personalized medicine. 
In vivo antitumor activity of NCyNP plus aPD-1. Immune checkpoint blockade has been

331 very successful in clinical cancer treatment, but the response rate is low ${ }^{15,46}$. The primary reason

332 for this low response rate is ineffective infiltration and/or activation of $\mathrm{T}$ lymphocytes ${ }^{15}$. The 333 inflammation caused by pyroptosis in the tumor microenvironment can recruit and activate large 334 numbers of $\mathrm{T}$ lymphocytes to improve the response rate of immune checkpoint blockade. 335 Encouraged by the robust antitumor immune response induced by $\mathrm{NCyNH}_{2}$, we surmised that this 336 strategy might enhance the anticancer efficacy of checkpoint inhibitors, such as $\alpha \mathrm{PD} 1$. Therefore, 337 we established a 4T1 tumor-bearing Balb/c mouse model, which is known to have a low response 338 rate to $\alpha \mathrm{PD} 1$ treatment ${ }^{17}$, to test the treatment effect of NCyNP combined with the immune 339 checkpoint inhibitor $\alpha$ PD1. Briefly, tumor-bearing mice were randomly divided into four groups (n $340=6)$ and treated with saline, aPD1, NCyNP or NCyNP plus $\alpha$ PD1 $\left(6 \mathrm{mg} \mathrm{kg}^{-1} \mathrm{NCyNH}_{2}, 100 \mu \mathrm{g}\right.$ $341 \alpha \mathrm{PD} 1$ per mouse). As shown in Fig. 5A, NCyNP therapy was administered by i.v. injection on days $3420,3,5$ and 7 , and $\alpha$ PD-1 therapy was administered by i.v. injection on days $6,8,10$ and 12 . Tumor 343 volume (Fig. 5B) and tumor weight (Fig. 5C) in the NCyNP plus $\alpha$ PD1 group were significantly 344 lower than in the other groups, and the NCyNP plus $\alpha \mathrm{PD} 1$ group presented the highest tumor

inhibition rate, reaching $71.5 \%$ (Fig. 5E). The corresponding tumor images are shown in Fig. 5D, which was highly consistent with the tumor inhibition study. H\&E staining, Ki67 staining and TUNEL staining of tumor sections (Fig. S27) clearly demonstrated that NCyNP plus $\alpha$ PD1 is an effective strategy to reduce tumor cell proliferation and increase the percentage of tumor cell apoptosis, consistent with the results of the therapeutic study. In addition, no significant weight loss or tissue damage in mice was observed through all treatments (Fig. S28 and S29), indicating that NCyNP-induced antitumor therapy is highly biocompatible. All of the above results suggest that NCyNPs can synergize with $\alpha$ PD1 to further enhance the antitumor effect.

To understand the effect of immune cells in combination therapy, tumor tissues and TDLNs were separated at the end of the antitumor study to detect the immune cell populations. As shown 
in Fig. 5F-L, significant enrichment of CTLs in tumor tissue and mature DCs in TDLNs was observed in the NCyNP and NCyNP plus $\alpha$ PD1 groups. Moreover, CTLs and mature DCs in mice treated with NCyNP plus aPD1 were significantly higher than in mice treated with NCyNP. Further flow cytometry analysis showed a significantly increased presence of CTLs and decreased Tregs in tumors within the tumor microenvironment in mice treated with NCyNP and NCyNP plus $\alpha$ PD1.

Compared to the PBS groups, mice treated with NCyNP or NCyNP plus $\alpha$ PD1 exhibited significantly increased concentrations of IFN- $\gamma$ (Fig. S30A) and TNF- $\alpha$ (Fig. S30B) in the serum, indicating that NCyNP plus $\alpha \mathrm{PD} 1$ induced a stronger antitumor immune response. These results indicate that $\mathrm{NCyNH}_{2}$ improves the response rate of $\alpha \mathrm{PD} 1$ and causes a strong immune response to enhance solid tumor therapy.

The above results confirmed that pyroptosis (initiated by NCyNP) promotes the infiltration and activation of $\mathrm{T}$ lymphocytes in the tumor microenvironment and synergizes with $\alpha \mathrm{PD} 1$ to induce antitumor immunity. We further verified whether this antitumor strategy is applicable in other tumor models. To this end, CT26 tumor-bearing Balb/c mice were randomly divided into four groups $(n=6)$ and treated as described in the 4T1 tumor model. As shown in Fig. S31A, the antitumor efficacy was similar to that in the 4T1 tumor model, and NCyNP plus $\alpha \mathrm{PD} 1$ treatment exhibited the most effective inhibition of tumor growth. No significant body weight changes, shown in Fig. S31B, indicate negligible side effects of this treatment. Additionally, while all mice in the PBS and $\alpha$ PD1 groups died within 32 days, mice in the NCyNP group took 44 days to die, and the NCyNP plus $\alpha$ PD1 group exhibited 33.3\% animal survival within 50 days (Fig. S31C). Therefore, NCyNP plus $\alpha$ PD1 could be an effective antitumor agent and prolongs survival in tumor-bearing mice.

Encouraged by NCyNP plus $\alpha$ PD-1 administration, which effectively activated the antitumor immune response, we surmised that it could generate an immune memory effect to prevent tumor recurrence. To this end, the spleen was separated to measure the proportions of memory T cells 7 
days after the final treatment by flow cytometry. As shown in Fig. 6A-6D and Fig. S32, the 381 percentages of $\mathrm{T}_{\mathrm{CM}}$ and $\mathrm{T}_{\mathrm{EM}}$ in mice treated with NCyNP plus $\alpha \mathrm{PD}-1$ were significantly higher than 382 the other groups. In addition, a lung metastatic tumor model was established as previously reported. Briefly, primary tumors were surgically removed from CT26 tumor-bearing mice 7 days after the 384 final treatment, and then CT26 tumor cells were injected into mice by intravenous infusion (Fig.

\section{METHODS}

2,3,3-Trimethylindolenine, iodoethane, phosphorus oxychloride $\left(\mathrm{POCl}_{3}\right)$, cyclohexanone, tin chloride $\left(\mathrm{SnCl}_{2}\right)$, triethylamine (TEA), p-nitrophenyl chloroformate (NPC), 3-nitrophenylboronic 
acid, meta-chloroperbenzoic acid (m-CPBA), 2,2'-dithiodiethanol, 1,6-hexanediol, triphosgene were purchased from Energy Chemical (Shanghai, China). Doxorubicin hydrochloride $(\mathrm{DOX} \cdot \mathrm{HCl})$ was purchased from Dalian Meilun Biotechnology Co. (Dalian, China). All other chemicals used in the experiments were of analytical grade and used without further purification. Hoechst 33342 were purchased from Thermo Fisher Scientific (Waltham, USA). RPMI 1640, trypsin-EDTA and penicillin-streptomycin were obtained from Gibco BRL (Eggenstein, Germany). Fetal bovine serum (FBS) was obtained from ExCell Biology, Inc (Shanghai, China). Recombinant human DT diaphorase (NQO1), dicoumarol and 3-(4,5-dimethylthiazol-2-yl)-2,5-diphenyltetrazolium bromide (MTT) was purchased from Sigma. Calcein-AM/PI Double Stain Kit was purchased from Bestbio (Shanghai, China). Flow cytometric antibodys for immune cell labeling were purchased from biolegend. Anti-mouse-PD1(CD279) was purchased from BioXcell.

NMR spectra were measured on a Bruker ARX 400 NMR spectrometer. The absorption spectra were measured on a UV-3802 (UNICO, Shanghai, China) spectrophotometer. Photoluminescence spectra were measured on a Shimadzu RF-6000 spectrofluorometer (Shimadzu UV-2600, Japan). Confocal images were acquired by confocal microscope (CLSM, Nikon Ti-E A1, Japan). Absorbance and fluorescence intensity were measured by a multifunctional micropore detection board analysis system (Biotek Cytation5, BioTek, United States).

Synthesis of compound 1. 2,3,3-Trimethylindolenine (1.6 g, $10.0 \mathrm{mmol})$ and iodoethane (2.34 g, $15.0 \mathrm{mmol}$ ) were dissolved in $\mathrm{CH}_{3} \mathrm{CN}(30 \mathrm{~mL})$. The mixture was refluxed for $24 \mathrm{~h}$. After the removal of solvent under reduced pressure, the resulting crude product was washed with nhexane three times to obtain a white solid product of compound $\mathbf{1}(2.8 \mathrm{mg}, 89.7 \%)$.

Synthesis of compound 2. The $\mathrm{CH}_{2} \mathrm{Cl}_{2}$ solution of phosphorus oxychloride $(5.3 \mathrm{~mL}, 34.5$ mmol) and cyclohexanone $(1.48 \mathrm{~g}, 15.0 \mathrm{mmol})$ were added dropwise into the mixture of $N, N$ dimethylformamide (DMF, $6.0 \mathrm{~mL})$ and $\mathrm{CH}_{2} \mathrm{Cl}_{2}(10 \mathrm{~mL})$ in an ice bath under $\mathrm{N}_{2}$ atmosphere. The 
reaction mixture was stirred and refluxed for $5 \mathrm{~h}$. Then the mixture was poured into ice and stay overnight. The mixture was filtered to collect a yellow solid product of compound $2(2.0 \mathrm{~g}, 78 \%)$.

Synthesis of compound 3. A mixture of compound $1(2.5 \mathrm{~g}, 8.0 \mathrm{mmol})$, compound 2 ( $0.7 \mathrm{~g}$, $4.0 \mathrm{mmol})$ and sodium acetate $(0.67 \mathrm{~g}, 8.0 \mathrm{mmol})$ in acetic anhydride $(40 \mathrm{~mL})$ was stirred at $130{ }^{\circ} \mathrm{C}$ for $1 \mathrm{~h}$. After the removal of solvent under reduced pressure, the crude product was washed with sodium bicarbonate solution and extracted with dichloromethane. The solvent was removed under reduced pressure and the crude product was purified by silica gel flash chromatography with dichloromethane/methanol in a volume ratio of 20:1 to afford compound $\mathbf{3}$ as a green powder (2.04 g, $80 \%)$.

Synthesis of 3-nitrophenol (compound 4). 3-Nitrophenylboronic acid (0.8 g, $5.0 \mathrm{mmol})$ and m-CPBA $(1.0 \mathrm{~g}, 6 \mathrm{mmol})$ were added into the flask at room temperature was dissolved in a $\mathrm{H}_{2} \mathrm{O}$ : EtOH (1:2) solution $(10 \mathrm{~mL})$ in a round-bottom flask. Sodium bicarbonate solution $(50 \mathrm{~mL})$ was added to the mixture after 3-nitrophenylboronic acid was completely consumed. The mixture was then extracted with ethyl acetate $(2 \times 50 \mathrm{~mL})$. The organic layer was collected and washed with sodium chloride solution $(50 \mathrm{~mL})$, dried over anhydrous sodium sulfate. The solvent was removed under reduced pressure, and then the crude product was purified by silica gel flash chromatography with n-hexane/ethyl acetate in a volume ratio of 4:1 to afford 3-nitrophenol as a colorless solid of compound $4(0.57 \mathrm{~g}, 86 \%)$.

Synthesis of compound 5. A mixture of compound 3 (640 mg, $1.0 \mathrm{mmol})$, 3-nitrophenol (167 $\mathrm{mg}, 1.2 \mathrm{mmol})$ and triethylamine $(121 \mathrm{mg}, 1.2 \mathrm{mmol})$ and in DMF (10 mL) was stirred at room temperature for $12 \mathrm{~h}$. The solvent was evaporated under reduced pressure and the precipitate was dissolved in $\mathrm{CH}_{2} \mathrm{Cl}_{2}$, followed by washing with sodium bicarbonate solution for three times and dried over anhydrous sodium sulfate. The crude product was purified by silica gel flash chromatography with dichloromethane/methanol in a volume ratio of 20:1 to afford compound $\mathbf{5}$ as a golden powder $(606 \mathrm{mg}, 85 \%)$. 
Synthesis of CyNH2. Compound $5(374 \mathrm{mg}, 0.5 \mathrm{mmol})$ was dissolved in $10 \mathrm{~mL} \mathrm{CH}_{3} \mathrm{OH}$.

$\mathrm{SnCl}_{2}(2.4 \mathrm{~g}, 12.5 \mathrm{mmol})$ dissolved in concentrated $\mathrm{HCl}(2.0 \mathrm{~mL})$ was added slowly to the above solution and refluxed overnight. Then, the mixture was neutralized by saturated $\mathrm{NaHCO}_{3}$.The precipitate was obtained by filtration and washed with $\mathrm{CH}_{2} \mathrm{Cl}_{2}$. The collected filtrate was washed with water and dried over anhydrous magnesium sulfate. The solvent was removed by evaporation under reduced pressure, and the crude product was purified by silica gel flash chromatography with dichloromethane/methanol in a volume ratio of 50:1 to afford $\mathrm{CyNH}_{2}$ as a green powder (189 mg, $72 \%)$.

Synthesis of compound 6. 2,3,5-Trimethylhydroquinone (4.0 g, $26.2 \mathrm{mmol})$ and 3,3dimethacrylic acid (2.9 g, $29.0 \mathrm{mmol})$ were dissolved in methanesulfonic acid $(20 \mathrm{~mL})$, then the reaction mixture was stirred at $85^{\circ} \mathrm{C}$ for $3 \mathrm{~h}$ under nitrogen atmosphere. After the mixture was cooled to room temperature, $700 \mathrm{~mL}$ of water was added and stirred for 20 mins, then the mixture was extracted with ethyl acetate $(3 \times 50 \mathrm{~mL})$. The collected organic layer was successively washed with sodium saturated sodium bicarbonate solution $(3 \times 100 \mathrm{~mL})$ and water $(3 \times 100 \mathrm{~mL})$. After dried over anhydrous magnesium sulfate, the organic phase was concentrated and recrystallized with $n$ hexane/ethyl acetate (1:1) to obtain a white solid $(4.9 \mathrm{~g}, 80 \%)$.

Synthesis of compound 7. Compound $6(3.16 \mathrm{~g}, 13.48 \mathrm{mmol})$ and NBS $(2.52 \mathrm{~g}, 14.16 \mathrm{mmol})$ were dissolved in a mixed solvent ( $30 \mathrm{~mL}$ acetonitrile and $6 \mathrm{~mL}$ water), and stirred for $30 \mathrm{~min}$ at room temperature. After the reaction, the collected organic layer was extracted with dichloromethane $(3 \times 50 \mathrm{~mL})$. The organic layer was collected and dried with anhydrous magnesium sulfate, and the product was obtained after vacuum distillation (3.2 $\mathrm{g}, 94.8 \%)$.

Synthesis of $\mathbf{N C y N H}_{2}$. Compound 7 (0.8 g, $\left.3.2 \mathrm{mmol}\right), 2$-(7-azabenzotriazole)- $N, N, N^{\prime}, N^{\prime}-$ tetramethylurea hexafluorophosphate (HATU) $(1.52 \mathrm{~g}, 4.0 \mathrm{mmol})$ and $N, N$-diisopropylethylamine (DIPEA) $(500 \mu \mathrm{L})$ was dissolved in dichloromethane $(60 \mathrm{~mL})$. After stirred at $0^{\circ} \mathrm{C}$ for $30 \mathrm{~min}$, $\mathrm{CyNH}_{2}(524 \mathrm{mg}, 1.0 \mathrm{mmol})$ was dissolved in dichloromethane $(10 \mathrm{~mL})$ and added dropwise to the 
above reaction solution, then the reaction mixture was stirred $24 \mathrm{~h}$ at $35^{\circ} \mathrm{C}$. The reaction mixture was precipitated into a large amount of methanol, collected the white solid and dissolve in $N, \mathrm{~N}$ dimethylformamide, then precipitated into methanol again, and the precipitation was repeated three times to obtain $\mathrm{NCyHN}_{2}(295 \mathrm{mg}, 39 \%)$.

Cell line and animals. Human breast cancer cells (MCF-7), human umbilical vein endothelial cells (HUVECs) and mouse embryonic fibroblast (MEF) were cultured in DMEM medium with $10 \%$ FBS, $1 \%$ penicillin-streptomycin. Mouse breast cancer cells (4T1), mouse colon cancer cells (CT26), human pancreatic cancer cells (Panc-2), human embryonic kidney cells (293T), human cervical cancer cells (HeLa), human lung adenocarcinoma (A549) and mouse melanoma cells (B16) were cultured in 1640 medium with $10 \%$ FBS, 1\% penicillin-streptomycin. Cells were cultured in $5 \% \mathrm{CO}_{2}$ and $21 \% \mathrm{O}_{2}$ incubator at $37{ }^{\circ} \mathrm{C}$. Female BALB/c mice $(20 \pm 2 \mathrm{~g}, 5-6$ weeks old $)$ were purchased from Hunan SJA Laboratory Animal Co., Ltd (Hunan, China). Animal studies were performed according to a protocol approved by the Ethics Committee of the South China University of Technology.

In vitro cellular uptake. The cellular uptake of $\mathrm{CyNH}_{2}$ was investigated by using a confocal laser scanning microscope (CLSM, Zeiss LSM 410, Germany). Briefly, 4T1 cells or CT26 cells were seeded into a $35 \mathrm{~mm}$ glass-bottom dishes at a density of $1 \times 10^{5}$ cells and incubated overnight. The cells were treated with $1 \mu \mathrm{g} \mathrm{mL} \mathrm{CyNH}_{2}$ for $0.5,1,2$ or $4 \mathrm{~h}$, respectively. After incubation, the cells were then washed with PBS and stained with Hoechst 33342 and studied by CLSM. The quantitative evaluation of cellular uptake was further evaluated by flow cytometry analysis. Briefly, 4T1 cells or CT26 cells were seeded in 24 -well plates at a density of $1 \times 10^{5}$ cells per well. After 24 $\mathrm{h}$ incubation, the culture medium was replaced with fresh medium containing $1 \mu \mathrm{g} \mathrm{mL} \mathrm{L}^{-1} \mathrm{CyNH}_{2}$ for $0.5,1,2$ or $4 \mathrm{~h}$, respectively. After incubating, the medium was removed, and the cells were washed with PBS for three times. The cells were trypsinized and $0.5 \mathrm{~mL}$ of cell suspension was taken to quantify the internalization by flow cytometry (BD Biosciences, USA). 
Intracellular localization of CyNH2. 4T1 or CT26 cells were seeded into $35 \mathrm{~mm}$ glass-

bottom dishes at a density of $5 \times 10^{4}$ cells and incubated overnight. Cells were incubated with $1 \mu \mathrm{g}$

$\mathrm{mL}^{-1} \mathrm{CyNH}_{2}$ for $4 \mathrm{~h}$. For colocalization experiments, cells were washed with PBS, and then 200

nM MitoTracker Green (Thermo Fisher, USA) was added and incubated at $37^{\circ} \mathrm{C}$ for $45 \mathrm{~min}$. After

staining with Hoechst 33342, the medium was removed, and cells were rinsed with PBS and imaged immediately by CLSM.

Mitochondrial membrane potential. Mitochondrial membrane potential was measured by MitoProbe ${ }^{\mathrm{TM}} \mathrm{JC}-1$ Assay Kit (Beyotime, China). 4T1 cells were seeded into a $35 \mathrm{~mm}$ glass-bottom dishes at a density of $5 \times 10^{4}$ cells and incubated overnight. Then the cells were treated with different concentrations $\left(0,1,2,4\right.$ and $\left.6 \mu \mathrm{g} \mathrm{mL} \mathrm{m}^{-1}\right)$ of $\mathrm{CyNH}_{2}$ for $6 \mathrm{~h}$ at $37{ }^{\circ} \mathrm{C}$, cells were washed three times with PBS and incubated with $50 \mathrm{nM} \mathrm{JC}-1$ for $30 \mathrm{~min}$. After stained with Hoechst 33342, the cells were washed, incubated with fresh medium, and imaged immediately by CLSM. For quantitative analysis, 4T1 cells were seeded into a 24 -well plate at a density of $1 \times 10^{5}$ cells and incubated overnight. Then the cells were treated with different concentrations $\left(0,1,2,4\right.$ and $\left.6 \mu \mathrm{g} \mathrm{mL} \mathrm{m}^{-1}\right)$ of $\mathrm{CyNH}_{2}$ for $6 \mathrm{~h}$ at $37^{\circ} \mathrm{C}$, cells were washed three times with PBS and incubated with $50 \mathrm{nM} \mathrm{JC}-1$ for $30 \mathrm{~min}$. After washed with PBS, the cells were collected, and the fluorescence intensity of cells were analyzed by flow cytometry.

OCR and MRR measurements. The OCR was measured using an Oxygen Consumption Rate Assay Kit (BestBio, China), according to the manufacturer's instructions. It is based an oxygen sensitive fluorescent probe with a maximum excitation wavelength at $468 \mathrm{~nm}$ and a maximum emission wavelength at $603 \mathrm{~nm}$. Its fluorescence reacts with oxygen through molecular collision and is quenched by $\mathrm{O}_{2}$. Therefore, the amount of fluorescent signal is inversely proportional to the amount of extracellular $\mathrm{O}_{2}$ in the sample. Thus, it can be used to monitor changes in extracellular oxygen consumption. Briefly, 4T1 cells were seeded into an opaque-walled 96-well at a density of $1 \times 10^{4}$ cells each well and incubated overnight. Then the cells were treated with different 
concentrations $\left(0,1,2,4\right.$ and $\left.6 \mu \mathrm{gL}^{-1}\right)$ of $\mathrm{CyNH}_{2}$ for $4 \mathrm{~h}$ at $37{ }^{\circ} \mathrm{C}$. The cells were washed with

PBS and incubated with $150 \mu \mathrm{L}$ fresh medium containing $10 \mu \mathrm{L}$ oxygen sensitive fluorescent probe, then $100 \mu \mathrm{L}$ oxygen blocking fluid was seeded into each well. The change in the fluorescence signal over time were reader by the microplate reader, the excitation was $468 \mathrm{~nm}$, and the emission filter was $603 \mathrm{~nm}$. The OCR was calculated from the change in the fluorescence signal over time.

The MRR were measured according to previously reported methods. Briefly, 4T1 cells were seeded into a 24-well at a density of $1 \times 10^{5}$ cells each well and incubated overnight. Then the cells were treated with different concentrations $(0,1,2,4$ and $6 \mu \mathrm{g} \mathrm{mL}-1)$ of $\mathrm{CyNH}_{2}$ for $4 \mathrm{~h}$ at $37^{\circ} \mathrm{C}$. The cells were washed with PBS buffer and incubated with fresh medium for $4 \mathrm{~h}$, and half of the cells were treated with $2 \mu \mathrm{M}$ of oligomycin A (Sigma, USA) to inhibit the synthesis of ATP. After that, the cells in each group were harvested and lysed. The level of intracellular ATP was quantitatively determined by ATP bioluminescent assay kit according to manufacturer's instruction (Beyotime). The MRR in support of ATP production was calculated before/after the oligomycin treatment.

Intracellular ROS levels. To study oxidative stress caused by $\mathrm{CyNH}_{2}$ treatment, levels of intracellular ROS were evaluated using the cell-permeable ROS sensor 2',7'-dichlorofluorescin diacetate (DCFH-DA, Sigma, USA), which can be oxidized by ROS to form fluorescent dichlorofluorescein (DCF). 4T1 cells were seeded into $35 \mathrm{~mm}$ glass-bottom dishes at a density of $5 \times 10^{4}$ cells and incubated for $24 \mathrm{~h}$. Afterward, the medium was discarded, and cells were incubated with fresh medium containing different concentrations $\left(0,1,2,4\right.$ and $\left.6 \mu \mathrm{g} \mathrm{mL}^{-1}\right)$ of $\mathrm{CyNH}_{2}$ for $8 \mathrm{~h}$. Cells were then washed with PBS followed by DCFH-DA staining at $37^{\circ} \mathrm{C}$ for $20 \mathrm{~min}$. DCF fluorescence images were acquired by confocal microscopy and quantitatively measured by a multifunctional micropore detection board analysis system.

Cellular ATP activity assay. Cellular ATP levels were measured using a firefly luciferasebased ATP assay kit (Beyotime, China) according to the manufacturer's instructions. Briefly, 4T1 cells were seeded in an opaque-walled 96-well at a density of $1 \times 10^{4}$ cells each well and incubated 
554 overnight. After the cells were incubated with fresh medium containing different concentrations $(0$ 1, 2, 4 and $6 \mu \mathrm{g} \mathrm{mL}^{-1}$ ) of $\mathrm{CyNH}_{2}$ for $8 \mathrm{~h}$, the cells in each group were harvested and lysed. The level 556 of intracellular ATP was quantitatively determined by ATP bioluminescent assay kit according to 557 manufacturer's instruction.

bright-field images every 10 minutes between $30 \mathrm{~min}$ and $130 \mathrm{~min}$ after incubation with $\mathrm{CyNH}_{2}(8$ $\mu \mathrm{g} \mathrm{mL} \mathrm{L}^{-1}$ ) on a CLSM. A time-lapse video was generated using the bright-field images to show the morphology changes.

Lactate dehydrogenase (LDH) release study. The amount of LDH in cell cultural medium was determined by colorimetry based on an 2-[4-iodophenyl]-3-[4-nitrophenyl]-5-phenyltetrazolium chloride chromogenic reaction catalyzed by diaphorase with LDH Release Assay Kit (Beyotime, China). 4T1 cells was seeded in 96-well plates at a density of $1 \times 10^{4}$ per well. After overnight incubation, $\mathrm{CyNH}_{2}$ at different concentrations $\left(0,2,4,6,8\right.$ and $\left.10 \mu \mathrm{g} \mathrm{mL}^{-1}\right)$ were added into the wells for $12 \mathrm{~h}$ incubation. $\mathrm{LDH}$ release reagents was added to the maximum enzyme activity sample control wells (untreated cell wells for subsequent lysis) by $10 \%$ of the volume of original medium $1 \mathrm{~h}$ before the measurement. Later the cells were centrifuged at $400 \mathrm{~g}$ for $5 \mathrm{~min}$ to obtain the supernatant. Subsequently, $120 \mu \mathrm{L}$ of the supernatants were added into corresponding wells of a new 96-wells plate. Then $60 \mu \mathrm{L}$ of $\mathrm{LDH}$ detection reagents was added to each well and incubated in the dark for $30 \mathrm{~min}$ after blending. The absorbance (A) was measured at $490 \mathrm{~nm}$. The rates of LDH release were calculated as follows: (Adrug-treated sample $\left.-A_{\text {sample control }}\right) /\left(A_{\text {the maximum enzyme activity }}\right.$ sample control - A $\left.\mathrm{A}_{\text {sample control }}\right) \times 100 \%$.

Cyt c release and caspase-3 activation. For Cyt c release, 4T1 cells were seeded into a 35 mm glass-bottom dishes at a density of $5 \times 10^{4}$ cells per well for overnight. The cells were incubated with $\mathrm{CyNH}_{2}$ at a concentration of $0,2,4,6$ or $8 \mu \mathrm{g} \mathrm{mL}^{-1}$ for $6 \mathrm{~h}$. Then the cells were fixed with $4 \%$ paraformaldehyde for 30 min at room temperature and washed three times with PBS. After fixation, 
the cells were permeabilized by $0.1 \%$ Triton $\mathrm{X}-100$ in PBS and incubated with a FITC anti cytochrome c antibody (Thermo Fisher, USA) at $4{ }^{\circ} \mathrm{C}$ overnight. After stained with Hoechst 33342 , the cells were washed with PBS for 3 times and imaged by confocal laser scanning microscope. For caspase-3 activity study, 4T1 cells was seeded in 96-well plates at a density of $1 \times 10^{4}$ per well. After overnight incubation, $\mathrm{CyNH}_{2}$ at different concentrations $\left(0,2,4,6,8\right.$ and $\left.10 \mu \mathrm{g} \mathrm{mL} \mathrm{m}^{-1}\right)$ were added into the wells for $8 \mathrm{~h}$ incubation. Intracellular caspase- 3 activation was monitored by Caspase-Glo $^{\circledR}$ 3/7 Assay (Beyotime, China) according to the manufacturer's instructions.

Western blot analysis. 4T1 cells were seeded into 24-well plates at a density of $1 \times 10^{5}$ per well. After overnight incubation, $\mathrm{CyNH}_{2}$ at different concentrations $\left(0,3,5,10 \mu \mathrm{g} \mathrm{mL} \mathrm{m}^{-1}\right)$ was added to the wells for $8 \mathrm{~h}$ incubation. Then, cells were lysed in buffer containing $50 \mathrm{mM}$ Tris, $150 \mathrm{mM}$ $\mathrm{NaCl}, 1 \mathrm{mM}$ EDTA, $0.1 \% \mathrm{NP}-40$, and protease inhibitors and clarified by spinning at 14,000 RPM for $10 \mathrm{~min}$ at $4^{\circ} \mathrm{C}$. Cell lysates were fractionated by $12 \%$ SDS-PAGE and then transferred to polyvinylidene difluoride (PVDF) membranes with anti-GSDME (Abcam, ab215191) used as the primary antibody.

In vitro Annexin V-FITC/PI assay. Apoptosis assays against 4T1 cells were performed to evaluate the death mechanism of $\mathrm{CyNH}_{2}$. $4 \mathrm{~T} 1$ cells were seeded into 24-well plates at a density of $1 \times 10^{5}$ per well and incubated overnight. Then, cells were incubated with different concentrations of $\mathrm{CyNH}_{2}\left(2,4,6,8\right.$, or $\left.10 \mu \mathrm{g} \mathrm{mL} \mathrm{m}^{-1}\right)$ for $12 \mathrm{~h}$. Cells were stained with Annexin V-FITC/PI (Beyotime, China) according to the instructions of the kit and then analyzed by FACS.

In vitro cytotoxicity assay. In vitro cell cytotoxicity was evaluated in MCF-7, 4T1, CT26, A549, B16, HeLa, Panc-2, MEF, HUVECs and 293T cells using a standard MTT assay. Briefly, cells at a density of $1 \times 10^{4}$ per well were seeded into 96-well plates. After overnight incubation, $\mathrm{CyNH}_{2}$ was added at different concentrations to the wells for 24 or $48 \mathrm{~h}$ incubation. Afterward, MTT solution $\left(10 \mu \mathrm{L}, 5 \mathrm{mg} \mathrm{mL}^{-1}\right)$ was added to each well for an additional $4 \mathrm{~h}$. The medium containing MTT solution was discarded, and dimethyl sulfoxide (DMSO, $200 \mu \mathrm{L}$ per well) was 
604 added to dissolve formazan crystals for $30 \mathrm{~min}$. Finally, a microplate reader was used to measure 605 absorbance at $490 \mathrm{~nm}$.

606 In vitro live/dead assay. 4T1 cells were seeded into $35 \mathrm{~mm}$ glass-bottom dishes with a density

607 of $1 \times 10^{5}$ per well. After treated with different concentrations $\left(0,2,4,6,8\right.$ and $\left.10 \mu \mathrm{g} \mathrm{mL}^{-1}\right)$ of $608 \mathrm{CyNH}_{2}$ for $24 \mathrm{~h}$, the Live/Dead kit (BestBio, China) was used for imaging cell viability. The dyes 609 Calcein AM and Propidium Iodide (PI) in the kit stains live and dead cells, respectively. The 610 fluorescence of Calcein AM and PI was observed by CLSM.

611 Fluorescence recovery of $\mathrm{NCyNH}_{2}$. Fluorescence changes of $\mathrm{NCyNH}_{2}$ were investigated by 612 fluorescence spectrophotometry after incubation with NQO1. Briefly, $\mathrm{NCyNH}_{2}\left(2 \mu \mathrm{g} \mathrm{mL}{ }^{-1}, 10 \%\right.$ 613 DMSO in PBS) treated with NQO1 $\left(40 \mu \mathrm{g} \mathrm{mL}^{-1}\right)$ and the changes in fluorescence over time were 614 studied. The fluorescence changes of $\mathrm{NCyNH}_{2}$ were further investigated in 4T1 cells. Briefly, 4T1 615 cells were seeded into $35 \mathrm{~mm}$ glass-bottom dishes at a density of $1 \times 10^{5}$ cells and incubated 616 overnight. 4T1 cells were incubated for an additional $12 \mathrm{~h}$ after $4 \mathrm{~h}$ of coincubation with $\mathrm{NCyNH}_{2}$ 617 or $\mathrm{CyNH}_{2}\left(1 \mu \mathrm{g} \mathrm{mL}^{-1}\right)$, and cells were pretreated with or without an NQO1 inhibitor (DIC, $\left.50 \mu \mathrm{M}\right)$ 618 for $1 \mathrm{~h}$ to inhibit intracellular NQO1 activity. Afterward, cells were washed with PBS, stained with 619 Hoechst 33342, and observed by CLSM.

In vitro cytotoxicity of $\mathrm{NCyNH}_{2}$. In vitro cytotoxicity of $\mathrm{NCyNH}_{2}$ to $\mathrm{MCF}-7,4 \mathrm{~T} 1, \mathrm{CT} 26$, A549, B16, HeLa, Panc-2, MEF, HUVECs and 293T cells were evaluated using a standard MTT assay. Briefly, cells at a density of $1 \times 10^{4}$ per well were seeded into 96 -well plates. After overnight incubation, $\mathrm{NCyNH}_{2}$ was added at different concentrations to the wells for 24 or $48 \mathrm{~h}$ incubation. Afterward, MTT solution $\left(10 \mu \mathrm{L}, 5 \mathrm{mg} \mathrm{mL}^{-1}\right)$ was added to each well for an additional $4 \mathrm{~h}$. The medium containing MTT solution was discarded and DMSO (200 $\mu \mathrm{L}$ per well) was added to dissolve formazan crystals for $30 \mathrm{~min}$. Finally, a microplate reader was used to measure absorbance at $490 \mathrm{~nm}$. 
ATP and HMGB-1 release. Extracellular secretion of ATP was tested using an ATP assay

kit. Briefly, 4T1 cells were seeded into a 24 -well at a density of $1 \times 10^{5}$ cells each well and incubated overnight. Afterward, the medium was discarded, and cells were incubated with fresh medium containing different concentrations $\left(0,2,4\right.$ and $\left.6 \mu \mathrm{gL}^{-1}\right)$ of $\mathrm{NCyNH}_{2}$. After $12 \mathrm{~h}$, the supernatants were collected and then conducted with centrifugation using $12,000 \mathrm{rpm}$ for $10 \mathrm{~min}$ at $4{ }^{\circ} \mathrm{C}$. The level of secreted ATP was quantitatively determined by ATP bioluminescent assay kit according to manufacturer's instruction. Intracellular HMGB1 distribution was tested using immunofluorescence analysis. Briefly, 4T1 cells were seeded in a $35 \mathrm{~mm}$ glass-bottom dishes at a density of $1 \times 10^{5}$ cells and incubated overnight. Afterward, the medium was discarded and cells were incubated with fresh medium containing different concentrations $\left(0,2,4\right.$ and $\left.6 \mu \mathrm{g} \mathrm{mL}^{-1}\right)$ of $\mathrm{NCyNH}_{2}$ for $12 \mathrm{~h}$. The supernatants were collected and then conducted with centrifugation using $12,000 \mathrm{rpm}$ for $10 \mathrm{~min}$ at $4{ }^{\circ} \mathrm{C}$, the extracellular levels of HMGB1 were quantitatively determined by mouse high mobility group protein B1ELISA kit (CUSBIO, CSB-E08225m) according to manufacturer's instruction. The cells were washed with PBS for three times, then fixed with $4 \%$ paraformaldehyde for 20 min and permeabilized with $0.1 \%$ Triton X-100 for 10 min. After blocking with 4\% BSA, the cells were incubated with anti-HMGB1 antibody (Proteintech, 10829-1-AP) for $1 \mathrm{~h}$ at room temperature, and then incubated with Alexa Fluor 488-conjugated secondary antibody (Thermo Fisher, R37116) for $30 \mathrm{~min}$. The cells were then stained with Hoechst 33342 for 20 min and observed using CLSM.

BMDC maturation in vitro. To investigate DC maturation in vitro, BMDCs were generated from the bone marrow of 5- to 6-week-old BALB/c mice. $4 \mathrm{~T} 1$ cells were pretreated with different concentrations of $\mathrm{NCyNH}_{2}\left(0,2,4,6 \mu \mathrm{g} \mathrm{mL} L^{-1}\right)$. Cells pretreated with PBS were used as a negative control. Afterwards, $1 \times 10^{6}$ immature DCs were cocultured with $1 \times 10^{5} 4 \mathrm{~T} 1$ cells pretreated with $\mathrm{NCyNH}_{2}$. After staining with anti-CD11c-FITC (Clone: N418), anti-CD80-PE (Clone: 16-10A1) 
In vivo prophylactic tumor vaccination study. The female Balb/c mice were randomly divided into three group with each group containing 6 mice. The 4T1 cells pretreated with $\mathrm{CyNH}_{2}$ or DOX (positive control) were used as cancer vaccines for in vivo experiment. The healthy mice were immunized with the corresponding cancer vaccines (containing $2 \times 10^{6}$ cells in $100 \mu \mathrm{L}$ sterile PBS) twice on day 0 and day 7 , respectively, by subcutaneous injection into mouse right axilla. As a control, sterile PBS instead of cancer cell vaccine was subcutaneously injected into the mice in control group on day 0 and day 7 , respectively. On day 14, all the mice in 4 groups were inoculated with $1 \times 10^{6} \mathrm{CT} 26$ cells into the left axilla. After that, the tumor growth of 4 groups were monitored by measuring the tumor volumes. The tumor volume $(\mathrm{V})$ was calculated as $\mathrm{V}=\mathrm{W}^{2} \times \mathrm{L} / 2$, where $\mathrm{W}$ and $\mathrm{L}$ are the width and length of the tumor, respectively.

In vivo antitumor activity assessment. Female $B A L B / c$ mice were subcutaneously injected with $4 \mathrm{~T} 1$ cell suspension in the bilateral infra-axillary dermis $\left(5 \times 10^{5}\right.$ cells on the right side per mouse and $2 \times 10^{5}$ cells on the left side per mouse). When the tumor volume on the right side reached approximately $100 \mathrm{~mm}^{3}$, mice were randomly divided into three groups and intratumorally injected with PBS, $\mathrm{NCyNH}_{2}$ and DOX ( $3 \mathrm{mg} \mathrm{kg}^{-1} \mathrm{DOX}$ and $\left.2 \mathrm{mg} \mathrm{kg}^{-1} \mathrm{NCyNH}_{2}\right)$ twice in the right tumor. The tumor volumes and body weights were measured every other day. The tumor volume (V) was calculated as $\mathrm{V}=\mathrm{W}^{2} \times \mathrm{L} / 2$, where $\mathrm{W}$ and $\mathrm{L}$ are the width and length of the tumor, respectively. The tumor weight and pulmonary metastasis in the lung were examined at day 27 after tumor implantation. Lungs were fixed in 4\% paraformaldehyde for hematoxylin and eosin (H\&E) staining followed by observation under an inverted microscope (Olympus IX71, Japan) equipped with a DP73 digital camera.

Preparation of NCyNP. The NCyNP was prepared by nanoprecipitation method. Briefly, a mixture containing $\mathrm{PEG}_{5 \mathrm{k}}-b-\mathrm{PLGA}_{8 \mathrm{k}}(10 \mathrm{mg})$ and $\mathrm{NCyNP}(2 \mathrm{mg})$ were dissolved in $1.0 \mathrm{~mL}$ of 
DMSO, and then gradually added into $10 \mathrm{~mL}$ of ultrapure water under stirring. After additional stirring for $2 \mathrm{~h}$, the solution was transferred into dialysis bag (MWCO 3500) to remove DMSO against ultrapure water for $24 \mathrm{~h}$, and the solution was filtered through a $0.45 \mu \mathrm{m}$ filter to obtain NCyNP.

Characterization of NCyNP. The size distribution was performed in triplicate using a zeta sizer (Nano ZS, Malvern Instruments) at $25^{\circ} \mathrm{C}$. The samples were diluted using ultrapure water. The drug loading capacity of $\mathrm{NCyNH}_{2}$ into $\mathrm{PEG}_{5 \mathrm{k}}-b$-PLGA $8 \mathrm{k}$ was determined through UV spectrophotometer based on the standard curve of $\mathrm{NCyNH}_{2}$.

In vivo combination therapy. For breast tumor-bearing mouse model, Female BALB/c mice were inoculated with $4 \mathrm{~T} 1$ cells $\left(5 \times 10^{5}\right.$ cells per mouse $)$ in right mammary pad. When the tumor volume reached to approximately $60 \mathrm{~mm}^{3}$, the mice were randomly divided into four groups and intravenously injected with PBS, $\alpha$ PD-1, NCyNP and NCyNP plus $\alpha$ PD-1 $\left(6 \mathrm{mg} \mathrm{kg}^{-1}\right.$ of NCyNH , $100 \mu \mathrm{g}$ per mouse of $\alpha \mathrm{PD}-1)$ for four times, respectively. The tumor volumes and body weights were measured every other day. The mice were sacrificed 18 days. The histological analysis was carried out after treatments. The tissues of each representative organs of the heart, liver, spleen, lung, kidney, and tumor tissues of the mice in five groups were excised, fixed in $4 \%$ paraformaldehyde, embedded in paraffin, sliced and stained with H\&E. Tumor sections were also stained with TUNEL apoptosis detection kit assay and then observed by CLSM.

For colon tumor-bearing mouse model, Female BALB/c mice were implanted with colon tumor cells $\left(5 \times 10^{5}\right.$ cells per mouse) and received different treatments as described above ("In vivo antitumor activity assessment" section). The tumor volumes and body weights were measured every other day. Moreover, the survival rates were also monitored throughout the whole study.

Anti-metastasis effect. Subcutaneous colorectal tumors were established and treated with different formulations as the methods described previously. The tumors were removed by surgery 7 days post last treatment, and $2 \times 10^{6}$ CT26 cells were administered intravenously via tail vein 
infusion into each BALB/c mouse. $20 \mathrm{~d}$ later, after sacrificed mice, the lungs were photographed and weighted. The tissues were fixed in $4 \%$ formaldehyde and embedded in paraffin. Paraffinembedded $8 \mu \mathrm{m}$ lung sections stained with $\mathrm{H} \& \mathrm{E}$ were prepared for immunohistochemical analysis.

Analysis of immune cells. In order to understand the underlying mechanism of the antitumor effect aroused by $\mathrm{NCyNH}_{2}$, a series of immune cells were analyzed by flow cytometry after staining with antibodies. For tumor tissue, tumors were excised, minced, and incubated in 1640 containing $1 \mathrm{mg} \mathrm{mL}^{-1}$ collagenase type I (Sigma, USA), $1 \mathrm{mg} \mathrm{mL}^{-1}$ collagenase type IV (Biosharp, China), $100 \mu \mathrm{g} \mathrm{mL}{ }^{-1}$ hyaluronidase (Sigma, USA) and $100 \mu \mathrm{g} \mathrm{mL}^{-1}$ DNase I (Biofroxx, Germany) for 40 min at $37^{\circ} \mathrm{C}$. Tumor cell suspensions were passed through a 200-mesh nylon mesh and resuspended in $40 \%$ percoll after centrifugation to collect lymphocytes by centrifugation. Fc receptors were blocked using anti-CD16/32 mAb (Clone: 93). For the analysis of $\mathrm{T}$ cells, cells were stained by anti-CD45-APC-Cy7 (Clone: 104), anti-CD3-FITC (Clone: 17A2), anti-CD4-BV510 (Clone: RM4-5) anti-CD8-BV785 (Clone:53-6.7) and DAPI according to the supplier's protocol. For the analysis of regulatory cells (Tregs), cells were stained by anti-CD45-APC-Cy7 (Clone: 104), antiCD3-FITC (Clone: 145-2C11), anti-CD4-BV510 (Clone: RM4-5), anti-Foxp3-PE (Clone: 150D) and DAPI according to the supplier's protocol. For the analysis of mature DCs, cells were stained by anti-CD45-APC-Cy7 (Clone: 104), anti-CD11c-PE-Cy7 (Clone: N418), anti-CD80-PE (Clone: 16-10A1) and DAPI according to the supplier's protocol. The axillary lymph nodes were harvested from the mice and prepared to single cell suspensions by mechanical grinding. Fc receptors were blocked using anti-CD16/32 mAb (Clone: 93). For the analysis of $\mathrm{T}$ cells, cells were stained by anti-CD45-APC-Cy7 (Clone: 104), anti-CD3-FITC (Clone: 17A2), anti-CD4-BV510 (Clone: RM4-5) anti-CD8-BV785 (Clone:53-6.7) and DAPI according to the supplier's protocol. For the analysis of mature DCs, cells were stained by anti-CD45-APC-Cy7 (Clone: 104), anti-CD11c-PECy7 (Clone: N418), anti-CD80-PE (Clone: 16-10A1) and DAPI according to the supplier's protocol. Furthermore, the spleens were also collected from the mice, which were then prepared to single cell 
suspensions by mechanical grinding. After that, the cell suspensions were harvested by

centrifugation at 1,500 rpm for $5 \mathrm{~min}$, followed by removal of red blood cells (RBCs) using

modified RBC lysis buffer at $4{ }^{\circ} \mathrm{C}$ for 5 min and washing twice using $1 \times \mathrm{PBS}$. Fc receptors were

blocked using anti-CD16/32 mAb (Clone: 93). For the analysis of T cells, cells were stained by anti-CD45-APC-Cy7 (Clone: 104), anti-CD3-FITC (Clone: 17A2), anti-CD4-BV510 (Clone:

RM4-5) anti-CD8-BV785 (Clone:53-6.7) and DAPI according to the supplier's protocol. For the analysis of memory T cells, cells were stained by anti-CD45-APC-Cy7 (Clone: 104), anti-CD3BV610 (Clone: 17A2), anti-CD4-BV510 (Clone: RM4-5) anti-CD8-BV785 (Clone:53-6.7), antiCD62L-FITC (Clone: MEL-14), anti-CD44-APC (Clone: IM7) and DAPI according to the supplier's protocol. Flow cytometry was performed by BD FACS Celesta (BD Biosciences, USA).

Statistical analysis. All the obtained data were expressed as mean \pm standard deviation.

Statistical significance of the treatment groups was evaluated using Student's t test or one-way analysis of variance (ANOVA) with the least significant difference post hoc test. ns, nonsignificant. $* P<0.05, * * P<0.01$, and $* * * P<0.001$ were considered statistically significant in analyses.

\section{References}

1 Fuchs, Y. \& Steller, H. Live to die another way: modes of programmed cell death and the signals emanating from dying cells. Nat Rev Mol Cell Biol 16, 329-344 (2015).

2 Wallach, D., Kang, T. B., Dillon, C. P. \& Green, D. R. Programmed necrosis in inflammation: Toward identification of the effector molecules. Science 352, aaf2154 (2016).

3 Zhang, Y., Chen, X., Gueydan, C. \& Han, J. Plasma membrane changes during programmed cell deaths. Cell Res 28, 9-21(2018).

4 Zhang, Z. et al. Gasdermin E suppresses tumour growth by activating anti-tumour immunity. Nature 579, 415 $420(2020)$.

5 Jorgensen, I., Rayamajhi, M. \& Miao, E. A. Programmed cell death as a defence against infection. Nat Rev Immunol 17, 151-164 (2017).

6 Kovacs, S. B. \& Miao, E. A. Gasdermins: Effectors of Pyroptosis. Trends Cell Biol 27, 673-684 (2017).

7 Shi, J., Gao, W. \& Shao, F. Pyroptosis: Gasdermin-Mediated Programmed Necrotic Cell Death. Trends Biochem Sci 42, 245-254 (2017).

8 Wu, D., Wang, S., Yu, G. \& Chen, X. Cell Death Mediated by the Pyroptosis Pathway with the Aid of Nanotechnology: Prospects for Cancer Therapy. Angew Chem Int Ed Engl 59, 2-19 (2020).

9 Chen, K. W. et al. Extrinsic and intrinsic apoptosis activate pannexin-1 to drive NLRP3 inflammasome assembly. EMBO J 38, e101638 (2019).

10 Galluzzi, L. et al. Molecular mechanisms of cell death: recommendations of the Nomenclature Committee on Cell Death 2018. Cell Death Differ 25, 486-541 (2018).

11 Kayagaki, N. et al. Caspase-11 cleaves gasdermin D for non-canonical inflammasome signalling. Nature 526, 666-671 (2015).

12 Shi, J. et al. Cleavage of GSDMD by inflammatory caspases determines pyroptotic cell death. Nature 526, 660-665 (2015). 
13 Gajewski, T. F. et al. Cancer immunotherapy strategies based on overcoming barriers within the tumor microenvironment. Curr Opin Immunol 25, 268-276 (2013).

14 Schumacher, T. N. \& Schreiber, R. D. Neoantigens in cancer immunotherapy. Science 348, 69-74 (2015). Sharma, P. \& Allison, J. P. The future of immune checkpoint therapy. Science 348, 56-61 (2015) Menon, S., Shin, S. \& Dy, G. Advances in Cancer Immunotherapy in Solid Tumors. Cancers (Basel) 8, 106 (2016).

Wang, Q. et al. A bioorthogonal system reveals antitumour immune function of pyroptosis. Nature 579, 421$426(2020)$.

Corrales, L., Matson, V., Flood, B., Spranger, S. \& Gajewski, T. F. Innate immune signaling and regulation in cancer immunotherapy. Cell Res 27, 96-108 (2017).

Jayaraman, P. et al. IL-1beta promotes antimicrobial immunity in macrophages by regulating TNFR signaling and caspase-3 activation. J Immunol 190, 4196-4204 (2013).

Rodell, C. B. et al. TLR7/8-agonist-loaded nanoparticles promote the polarization of tumour-associated macrophages to enhance cancer immunotherapy. Nat Biomed Eng 2, 578-588 (2018).

Kroemer, G., Galluzzi, L., Kepp, O. \& Zitvogel, L. Immunogenic cell death in cancer therapy. Аnпu Rev Immunol 31, 51-72 (2013).

Min, Y. et al. Antigen-capturing nanoparticles improve the abscopal effect and cancer immunotherapy. Nat Nanotechnol 12, 877-882 (2017).

Zhou, B. et al. Tom 20 senses iron-activated ROS signaling to promote melanoma cell pyroptosis. Cell Res $\mathbf{2 8}$, 1171-1185 (2018).

Ploetz, E. et al. Metal-Organic Framework Nanoparticles Induce Pyroptosis in Cells Controlled by the Extracellular pH. Adv Mater 32, e1907267 (2020).

Jiang, W. et al. $\mathrm{NaCl}$ Nanoparticles as a Cancer Therapeutic. Adv Mater 31, e1904058 (2019).

Liu, Y., Zhen, W., Wang, Y., Song, S. \& Zhang, H. Na2S2O8 Nanoparticles Trigger Antitumor Immunotherapy through Reactive Oxygen Species Storm and Surge of Tumor Osmolarity. J Am Chem Soc 142, 21751-21757 (2020).

Wang, L. et al. Metformin induces human esophageal carcinoma cell pyroptosis by targeting the miR497/PELP1 axis. Cancer Lett 450, 22-31 (2019).

Li, J. J., Anraku, Y. \& Kataoka, K. Self-Boosting Catalytic Nanoreactors Integrated with Triggerable Crosslinking Membrane Networks for Initiation of Immunogenic Cell Death by Pyroptosis. Angew Chem Int Edit 59, 13526-13530 (2020).

9 Wu, M. et al. Activation of Pyroptosis by Membrane-Anchoring AIE Photosensitizer Design: New Prospect for Photodynamic Cancer Cell Ablation. Angew Chem Int Ed Engl, doi:10.1002/anie.202016399 (2021).

Fan, J. X. et al. Epigenetics-Based Tumor Cells Pyroptosis for Enhancing the Immunological Effect of Chemotherapeutic Nanocarriers. Nano Lett 19, 8049-8058 (2019).

Kenry, Chong, K. C. \& Liu, B. Reactivity-Based Organic Theranostic Bioprobes. Acc Chem Res 52, 30513063 (2019).

2 Belinsky, M. \& Jaiswal, A. K. NAD(P)H:quinone oxidoreductase1 (DT-diaphorase) expression in normal and tumor tissues. Cancer Metastasis Rev 12, 103-117 (1993).

Wang, Y. et al. Chemotherapy drugs induce pyroptosis through caspase-3 cleavage of a gasdermin. Nature 547, 99-103, doi:10.1038/nature22393 (2017).

Lu, Y., Aimetti, A. A., Langer, R. \& Gu, Z. Bioresponsive materials. Nat Rev Mater 2, 16075 (2017).

Yao, C. et al. Cytosolic NQO1 Enzyme-Activated Near-Infrared Fluorescence Imaging and Photodynamic Therapy with Polymeric Vesicles. ACS Nano 14, 1919-1935 (2020).

Dong, Y. et al. A General Strategy for Macrotheranostic Prodrug Activation: Synergy between the Acidic Tumor Microenvironment and Bioorthogonal Chemistry. Angew Chem Int Ed Engl 59, 7168-7172 (2020).

Yang, W. et al. Size-transformable antigen-presenting cell-mimicking nanovesicles potentiate effective cancer immunotherapy. Sci Adv 6, eabd1631 (2020).

Rodriguez-Ruiz, M. E. et al. Abscopal Effects of Radiotherapy Are Enhanced by Combined Immunostimulatory mAbs and Are Dependent on CD8 T Cells and Crosspriming. Cancer Res 76, 5994-6005 (2016).

9 Chen, Q. et al. Photothermal therapy with immune-adjuvant nanoparticles together with checkpoint blockade for effective cancer immunotherapy. Nat Commun 7, 13193 (2016).

Ngwa, W. et al. Using immunotherapy to boost the abscopal effect. Nat Rev Cancer 18, 313-322 (2018).

Mao, D. et al. AIEgen-coupled upconversion nanoparticles eradicate solid tumors through dual-mode ROS activation. Sci $A d v$ 6, eabb2712 (2020).

2 Li, Q. et al. IDO-inhibitor potentiated immunogenic chemotherapy abolishes primary tumor growth and eradicates metastatic lesions by targeting distinct compartments within tumor microenvironment. Biomaterials 269, 120388 (2020).

Vanpouille-Box, C. et al. DNA exonuclease Trex1 regulates radiotherapy-induced tumour immunogenicity. Nat Commun 8, 15618 (2017). 
44 Spranger, S. et al. Up-regulation of PD-L1, IDO, and T(regs) in the melanoma tumor microenvironment is driven by CD8(+) T cells. Sci Transl Med 5, 200ra116 (2013).

45 Mempel, T. R., Henrickson, S. E. \& Von Andrian, U. H. T-cell priming by dendritic cells in lymph nodes occurs in three distinct phases. Nature 427, 154-159 (2004).

46 Ribas, A. \& Wolchok, J. D. Cancer immunotherapy using checkpoint blockade. Science 359, 1350-1355(2018).

\section{Acknowledgments}

Funding: This work was supported by the National Natural Science Foundation of China (51873072, 52073101), the Science and Technology Program of Guangzhou (202002030268), Guangdong Provincial Pearl River Talents Program (2019QN01Y088).

Author contributions: K.W., Y.Y. conceived the project; X.X., M.J. and J.L. carried out chemical synthesis experiment; K.W. and J.Z. carried out cells and an animal experiments; K.W., Y.Y. provided guidance on experimental design and wrote the manuscript.

Competing interests: The authors declare that they have no competing interests.

Data availability: All the data supporting the findings of this study are available within the article and its Supplementary information files and from the corresponding author upon reasonable request. 

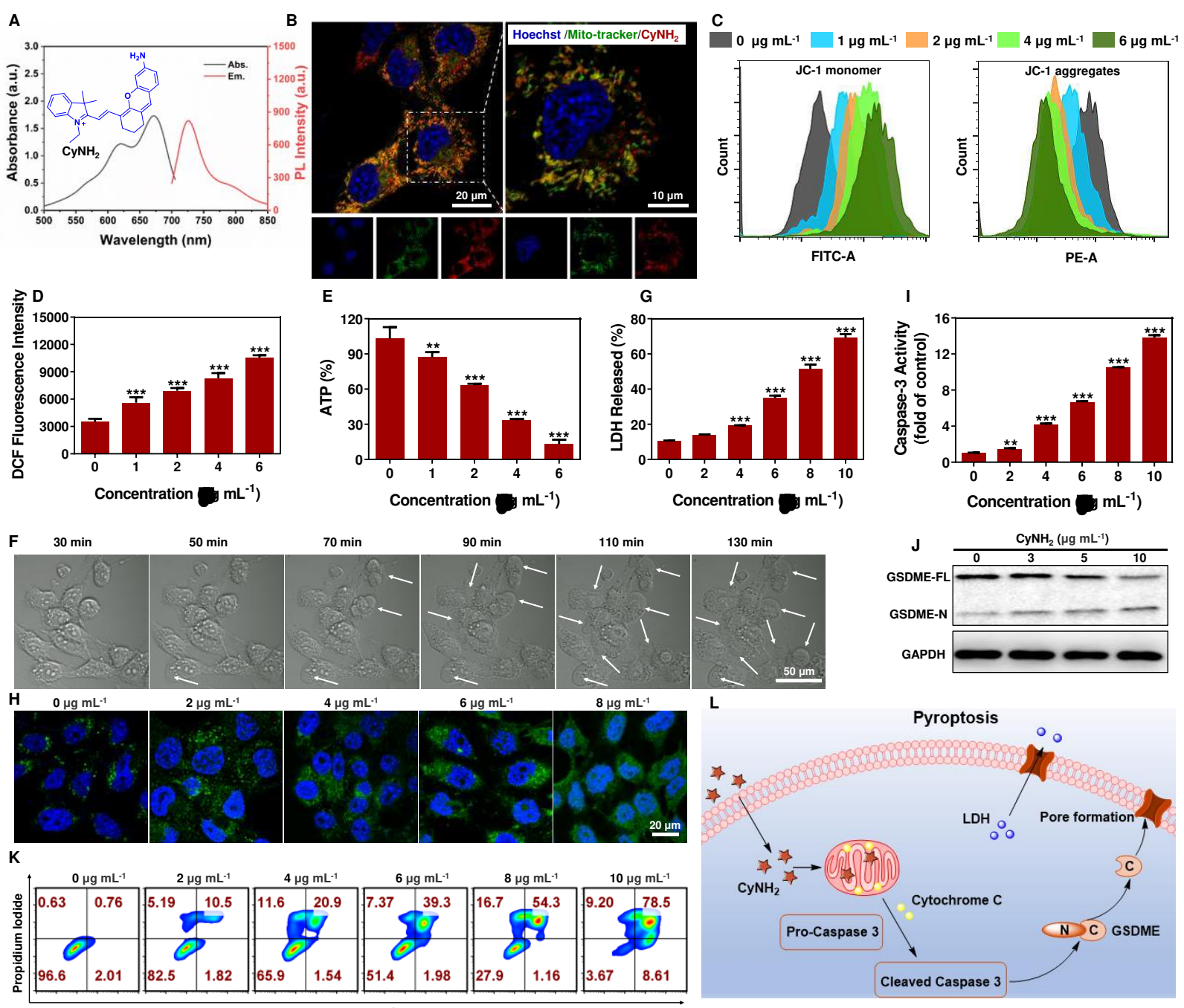

Annexin V-FITC

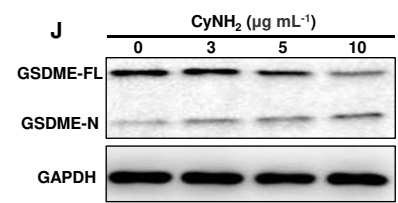

Fig. 1. $\mathrm{CyNH}_{2}$ induces cell pyrolysis. (A) The chemical structure, absorption and emission spectra of $\mathrm{CyNH}_{2}$. (B) The intracellular localization of $\mathrm{CyNH}_{2}$ in $4 \mathrm{~T} 1$ cells. (C) Flow cytometry analysis of changes in mitochondrial membrane potential after incubation with different concentrations of $\mathrm{CyNH}_{2}$. (D, E) The levels of intracellular reactive oxygen species (D) and intracellular ATP (E) after incubation with different concentrations of $\mathrm{CyNH}_{2}$. (F) Cellular morphology changes over time in $4 \mathrm{~T} 1$ cells pretreated with $\mathrm{CyNH}_{2}\left(8 \mu \mathrm{g} \mathrm{mL}^{-1}\right)$ for $2 \mathrm{~h}$; the white arrows indicate pyroptotic cells. (G-J) LDH release $(\mathrm{G})$, intracellular localization of cytoplasmic cyt c (H), intracellular caspase-3 activation (I) and western blotting analysis of pyroptosis-related protein expression (GSDME-FL, GSDME-N) (J) in 4T1 cells after treatment with different concentrations of $\mathrm{CyNH}_{2}$. (K) Flow cytometry analysis of apoptosis and necrosis in 4T1 cells treated with different concentrations of $\mathrm{CyNH}_{2}$. (L) Schematic diagram of the mechanism of $\mathrm{CyNH}_{2}$-induced cell pyrolysis. Data are presented as the mean $\pm \mathrm{SD}$. Statistical analysis was performed using the one-way ANOVA test $(* P<0.05, * * P<0.01$, and $* * * P<0.001)$. 
A
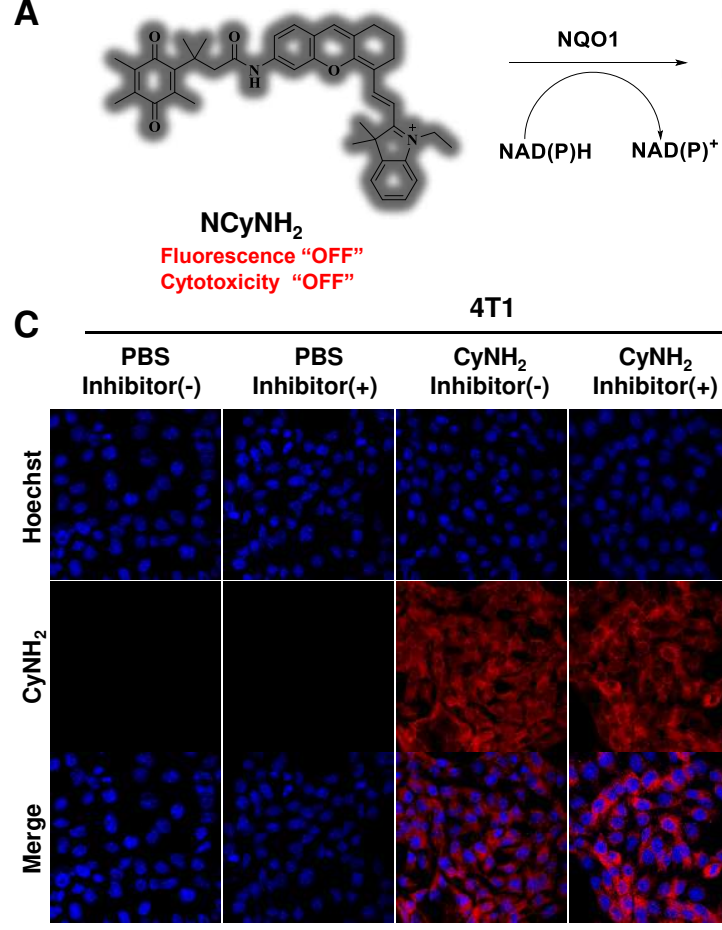
$\underset{\text { CyNH }}{\mathrm{CyN}_{2}}$

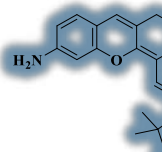

ctive $\mathrm{CyNH}_{2}$

Fluorescence "ON" Cytotoxicity "ON"

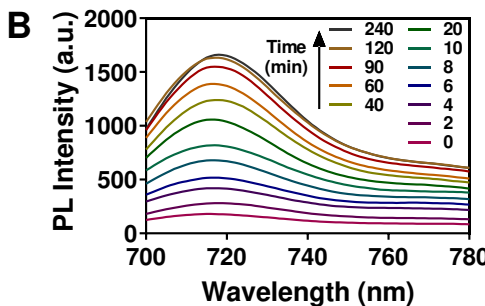

Wavelength (nm)

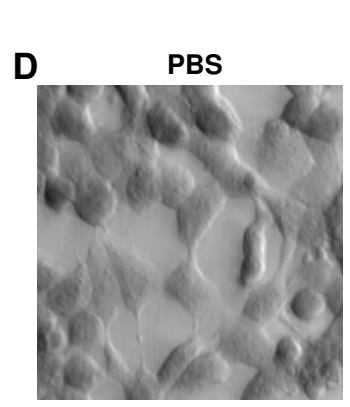

$\mathrm{CyNH}_{2}$ Inhibitor(-) $\mathrm{NCyNH}_{2} \quad \mathrm{NCyNH}_{2}$ Inhibitor(-) Inhibitor(+)
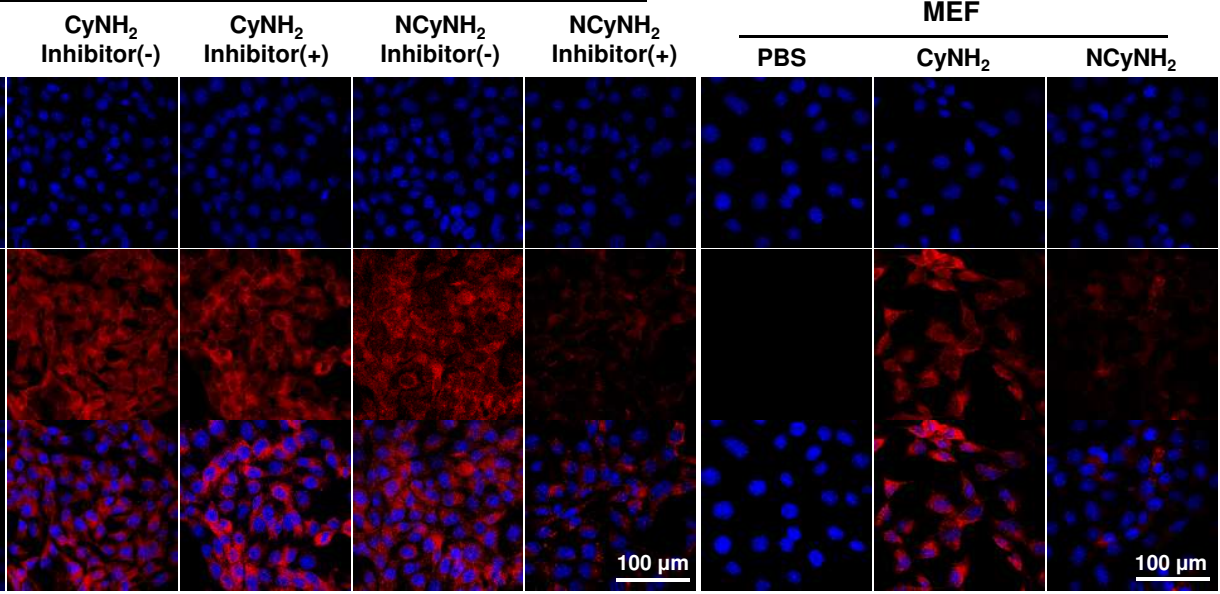

$\mathrm{CyNH}_{2}$

$\mathrm{NCyNH}_{2}$ Inhibitor(-)

$\mathrm{NCyNH}_{2}$ Inhibitor(+)
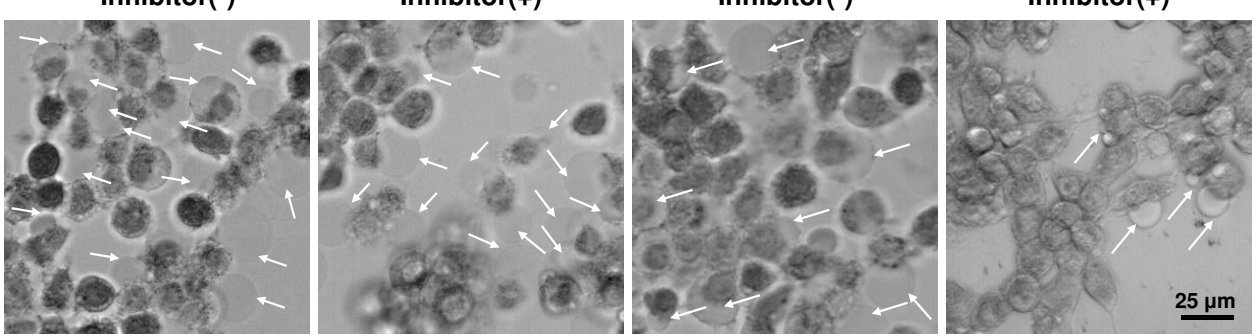

E

PBS

$\mathrm{CyNH}_{2}$

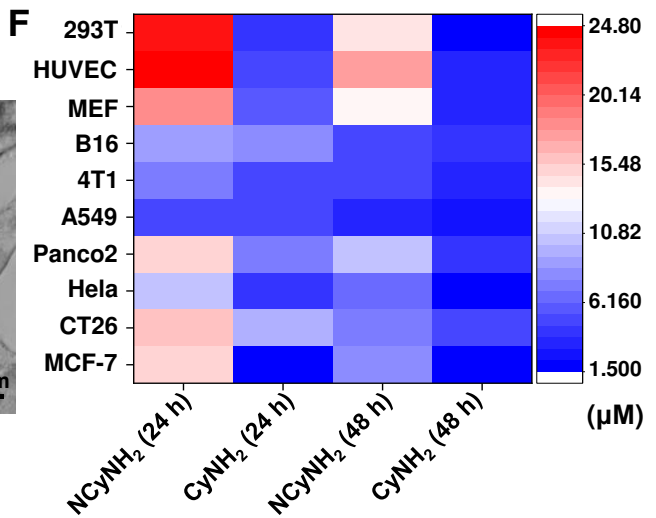

Fig. 2. Tumor cell selectivity of NCyNH2. (A) Schematic of intracellular NQO1-triggered cleavage of quinone trimethyl lock moieties of $\mathrm{NCyNH}_{2}$, accompanied by NIR emission turn-on and restored cytotoxicity due to release of $\mathrm{CyNH}_{2}$. (B) Evolution of fluorescence emission spectra $\left(\lambda_{\text {ex }}=670 \mathrm{~nm}\right)$ of $\mathrm{NCyNH}_{2}\left(2 \mu \mathrm{g} \mathrm{mL}^{-1}\right)$ upon incubation with NQO1 $\left(40 \mu \mathrm{g} \mathrm{mL}^{-1}, 0.1 \mathrm{mM} \mathrm{NADH}\right.$,

870 cells and MEFs treated with $\mathrm{CyNH}_{2}$ or $\mathrm{NCyNH}_{2}\left(1 \mu \mathrm{g} \mathrm{mL}^{-1}\right)$ for $24 \mathrm{~h}$ in the absence or presence of 
871 an NQO1 inhibitor (50 $\mathrm{M}$ DIC, $1 \mathrm{~h}$ pretreatment). (D) Representative cell morphology of 4T1 872 cells after treatment with $\mathrm{CyNH}_{2}$ or $\mathrm{NCyNH}_{2}\left(8 \mu \mathrm{gLL}^{-1}\right)$ for $8 \mathrm{~h}$ in the absence or presence of an 873 NQO1 inhibitor (50 $\mu \mathrm{M}$ DIC, $1 \mathrm{~h}$ pretreatment). (E) Representative cell morphology of MEFs after 874 treatment with $\mathrm{CyNH}_{2}$ or $\mathrm{NCyNH}_{2}\left(8 \mu \mathrm{g} \mathrm{mL}^{-1}\right)$ for $8 \mathrm{~h}$. (F) Comparison of $\mathrm{IC}_{50}$ values of $\mathrm{CyNH}_{2}$ 875 and $\mathrm{NCyNH}_{2}$ in different cell lines. 

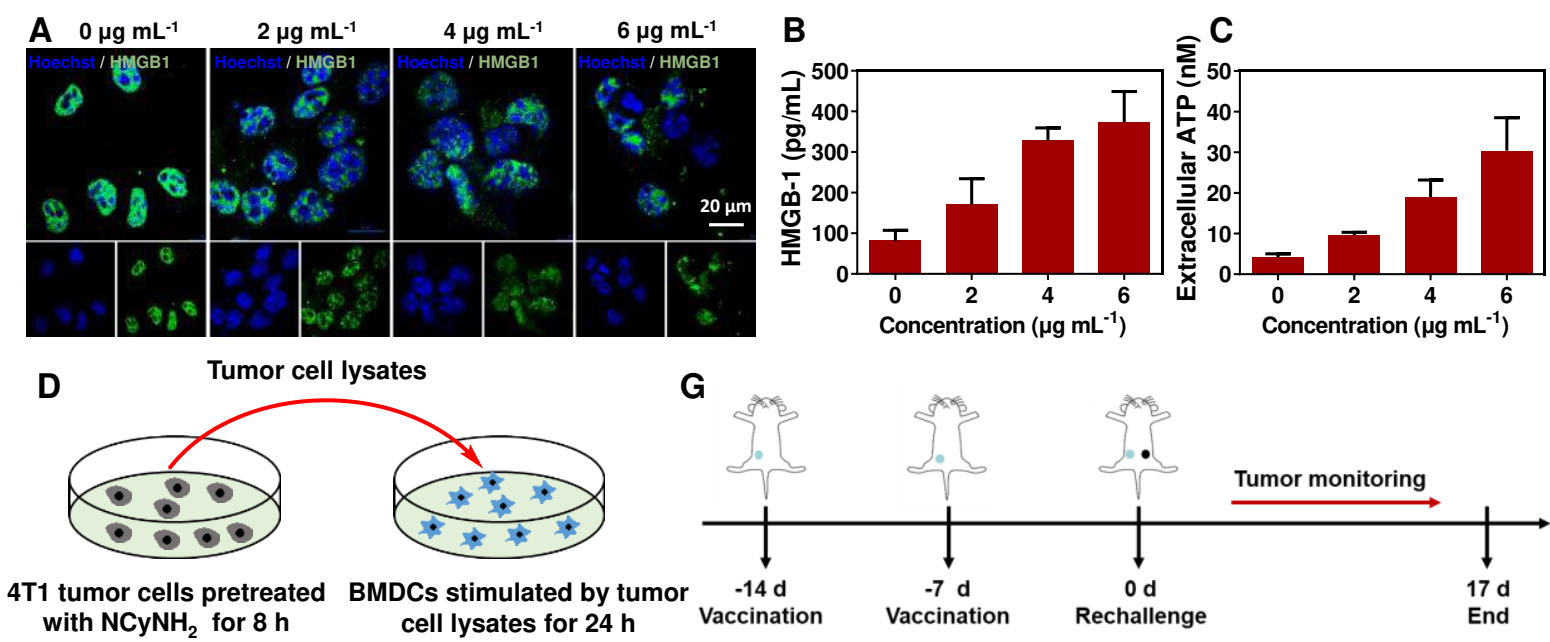

G

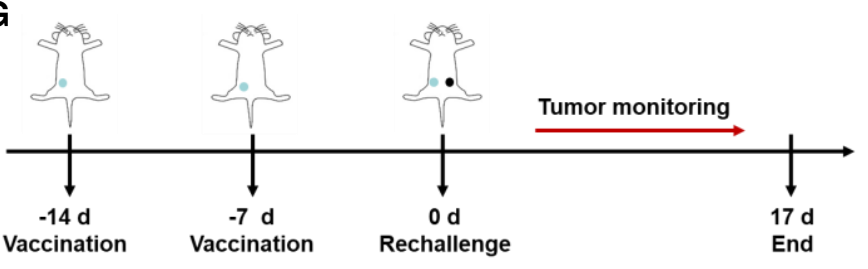
E
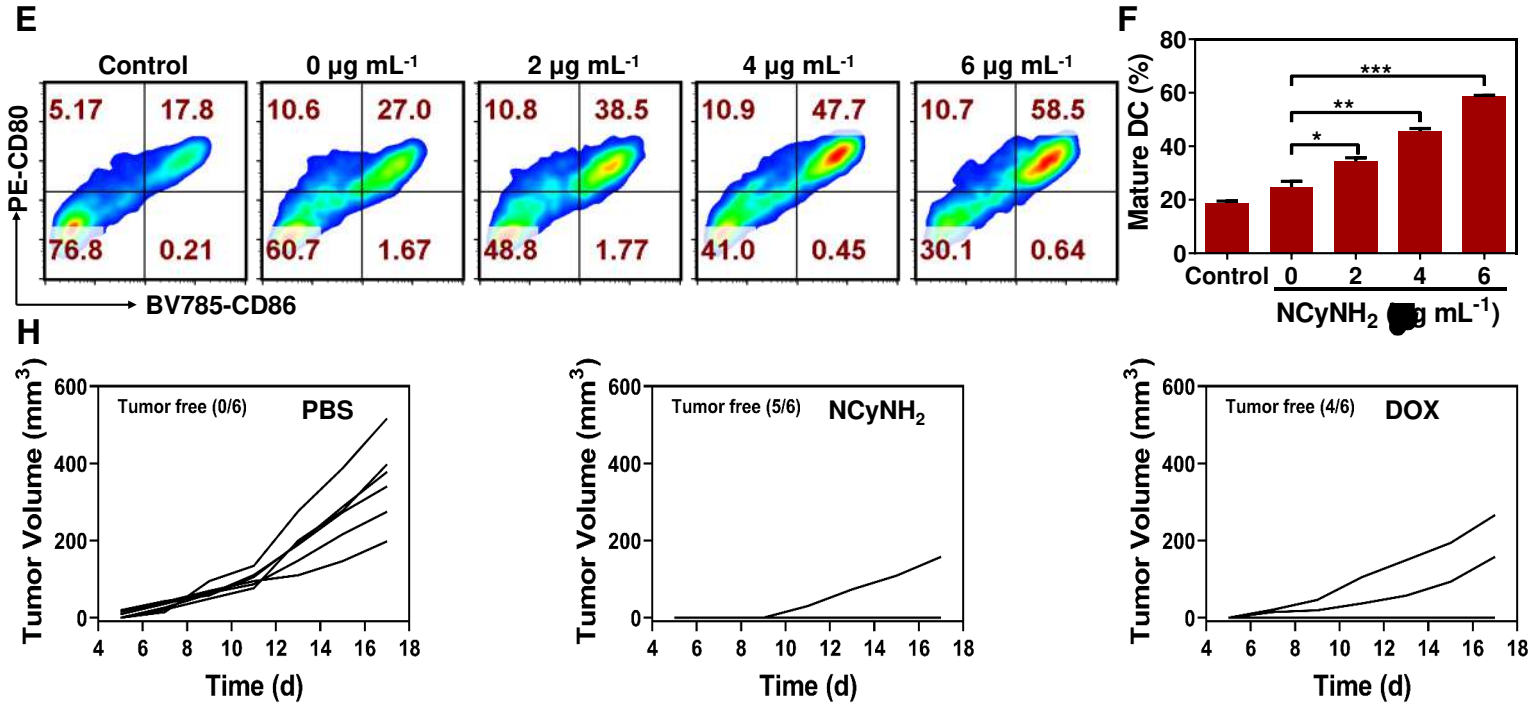

Fig. 3. Mature mouse bone marrow-derived dendritic cells (BMDCs) and in vivo prophylactic tumor vaccination study. (A) CLSM examination of HMGB1 release in 4T1 cells after treatment with different concentrations of $\mathrm{NCyNH}_{2}$. Quantitative examination of HMGB1 release (B) and ATP secretion (C) in 4T1 tumor cells after treatment with different concentrations of $\mathrm{NCyNH}_{2}$. (D) Schematics showing the experimental procedure of stimulating BMDCs with cell lysates from cancer cells after being treated with different concentrations of $\mathrm{NCyNH}_{2}$. Representative flow cytometry images (E) and corresponding quantification (F) of mature DCs $\left(\mathrm{CD} 11 \mathrm{c}^{+} \mathrm{CD}^{+} 0^{+} \mathrm{CD}^{+} 6^{+}\right)$after stimulation with 4T1 cell lysates and treatment with different concentrations of $\mathrm{NCyNH}_{2}$. (G) Vaccination approach in vivo of $\mathrm{NCyNH}_{2}$ - or $\mathrm{DOX}$-treated dying 4T1 cells incubated subcutaneously at 0 and $7 \mathrm{~d}$, followed by injection of untreated cells in the opposite flank 14 days later. $(\mathrm{H})$ Growth of second tumors after vaccination. Data are presented as the mean $\pm \mathrm{SD}$. Statistical analysis was performed using the one-way ANOVA test $(* P<0.05, * * P$ $<0.01$, and $* * * P<0.001)$. 

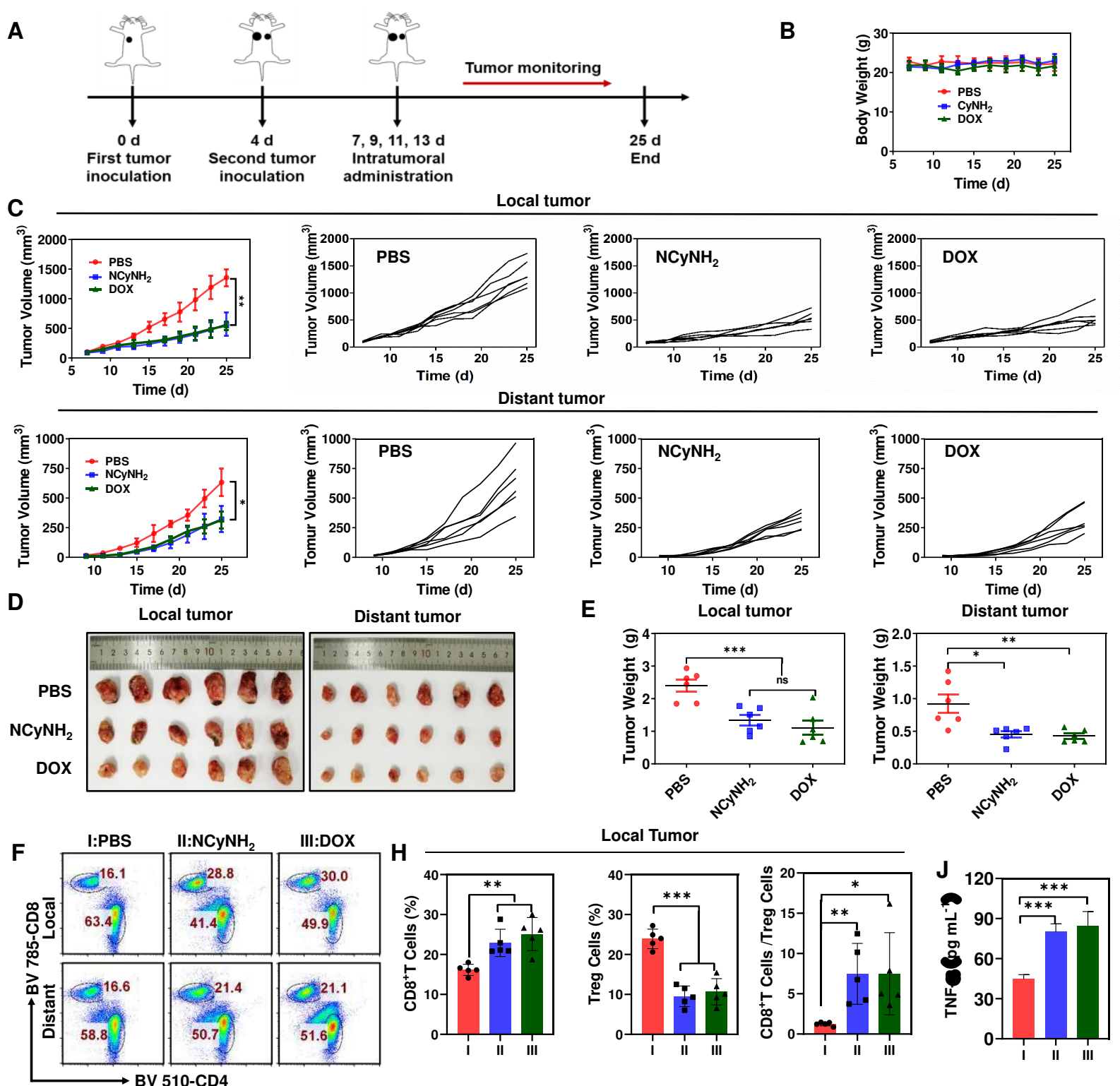

Local Tumor
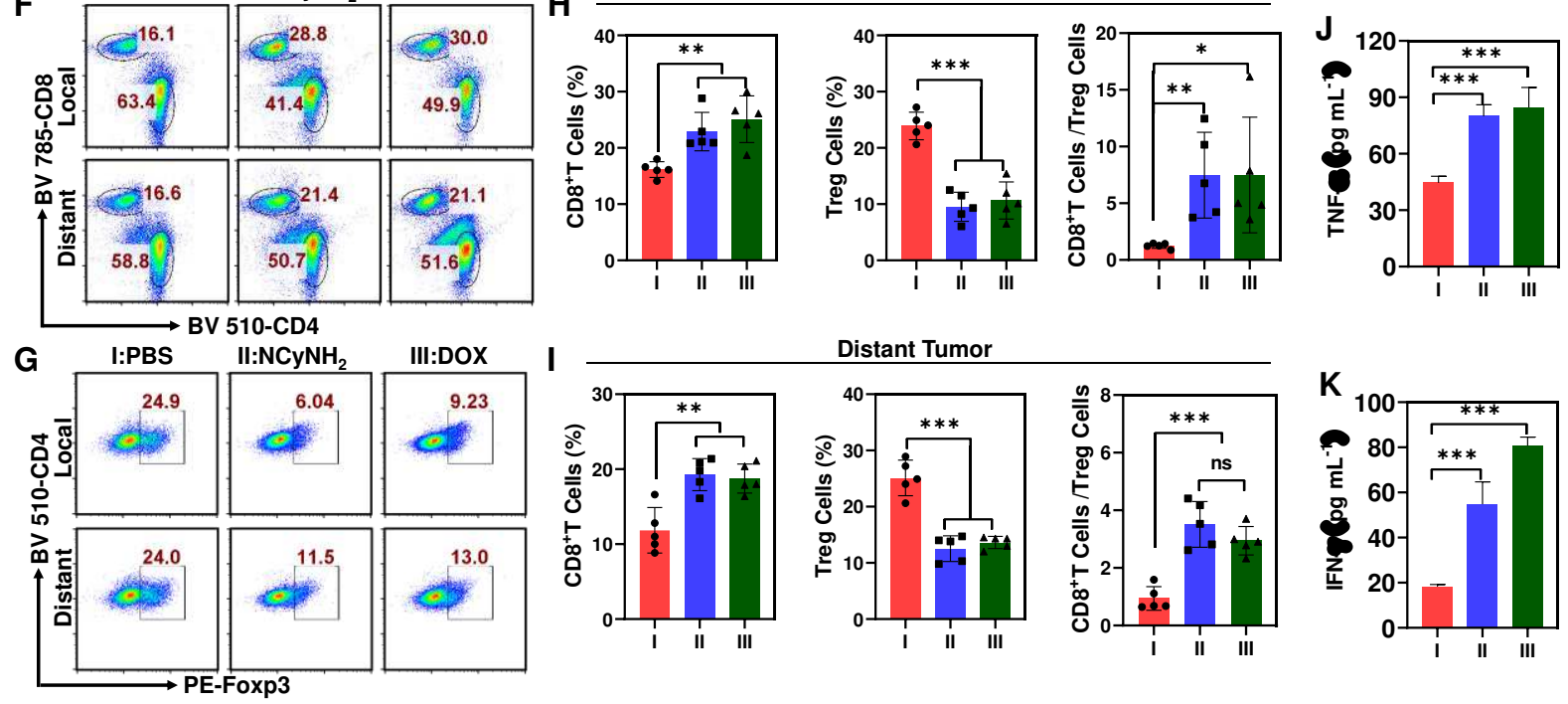

\section{Distant Tumor}
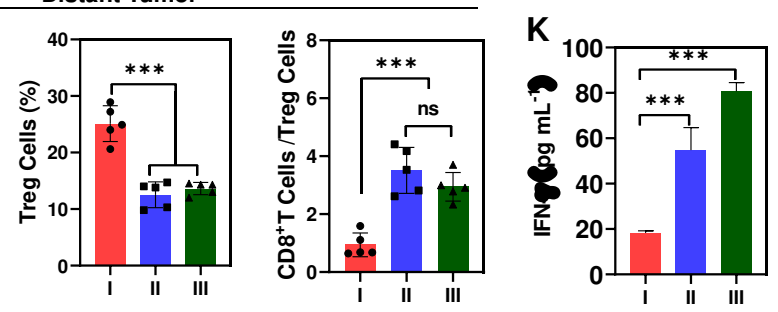

Fig. 4. In vivo antitumor effects of localized delivery of $\mathrm{NCyNH}_{2}$ in $4 \mathrm{~T} 1$ tumor-bearing

mice. (A) Schematic illustration of 4T1 tumor-bearing mice where only the local tumor (right side) received intratumoral injection (i.t.) of PBS, DOX $\left(3 \mathrm{mg} \mathrm{kg}^{-1}\right)$ or $\mathrm{NCyNH}_{2}\left(2 \mathrm{mg} \mathrm{kg}^{-1}\right)$ four times (7, 9, 11, 13 days after tumor implantation). (B) Body weight changes over the course of treatment. (C) Growth curves of local (right side) tumors and distant (left side) tumors in 4T1 tumor-bearing mice with local tumors intratumorally injected with $\mathrm{PBS}, \mathrm{NCyNH}_{2}$ or $\mathrm{DOX}$ as described in (A). (D, E) Tumor images (D) and relative tumor weights (E) of bilateral tumors (local and distant) isolated 
901 from 4T1 tumor-bearing mice receiving the treatments indicated in (A). (F) Representative flow 902 cytometry images of $\mathrm{CD}^{+} \mathrm{T}$ cells in $\mathrm{CD} 45^{+} \mathrm{CD}^{+}$tumor-infiltrating leukocytes. (G) Representative 903 flow cytometry images of Treg cells $\left(\mathrm{CD} 45^{+} \mathrm{CD}^{+} \mathrm{CD}^{+}{ }^{+} \mathrm{Foxp} 3^{+}\right)$in tumor-infiltrating $\mathrm{CD} 4^{+} \mathrm{T}$ cells 904 in tumor tissues at the end of antitumor therapy. (H, I) Corresponding quantification of the 905 percentage of $\mathrm{CD}^{+} \mathrm{T}$ cells in the $\mathrm{CD} 45^{+} \mathrm{CD}^{+}$tumor infiltrating leukocytes, Treg cells in the tumor 906 infiltrating $\mathrm{CD}^{+} \mathrm{T}$ cells and the ratio of $\mathrm{CD}^{+} \mathrm{T}$ cells/Treg cells based on the analysis of FACS 907 examination in local tumor tissue $(\mathrm{H})$ and distant tumor tissue (I). (J, K) TNF- $\alpha(\mathrm{J})$ and IFN- $\gamma(\mathrm{K})$ 908 levels in serum after different treatments. Data are presented as the mean \pm SD. Statistical analysis 909 was performed using the Student's t test (ns, nonsignificant. $* P<0.05$, ** $P<0.01$, and $* * * P<$ $910 \quad 0.001)$. 
A

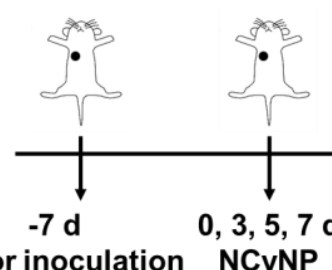

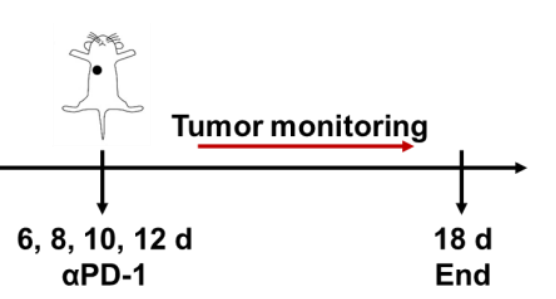

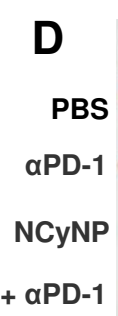

B
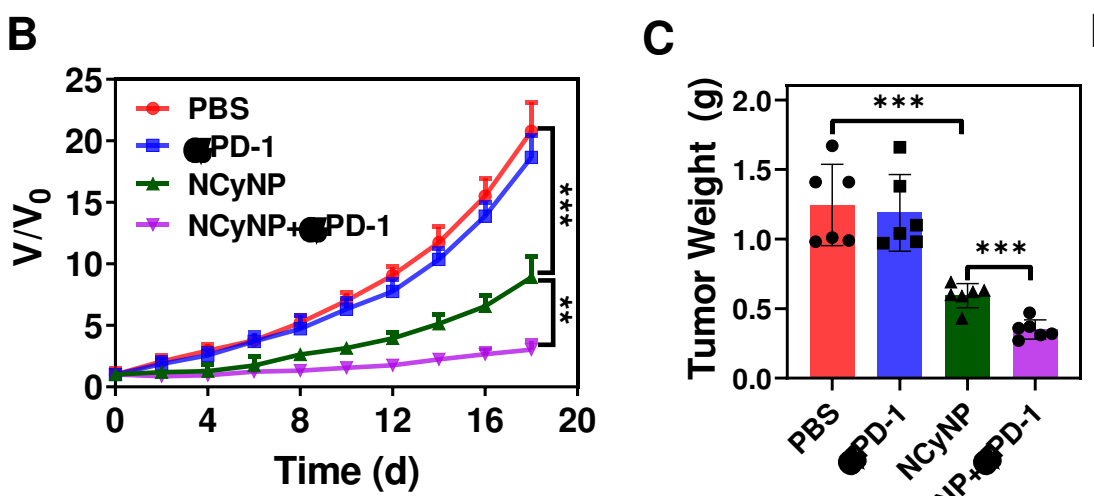

E $\widehat{\circ}$
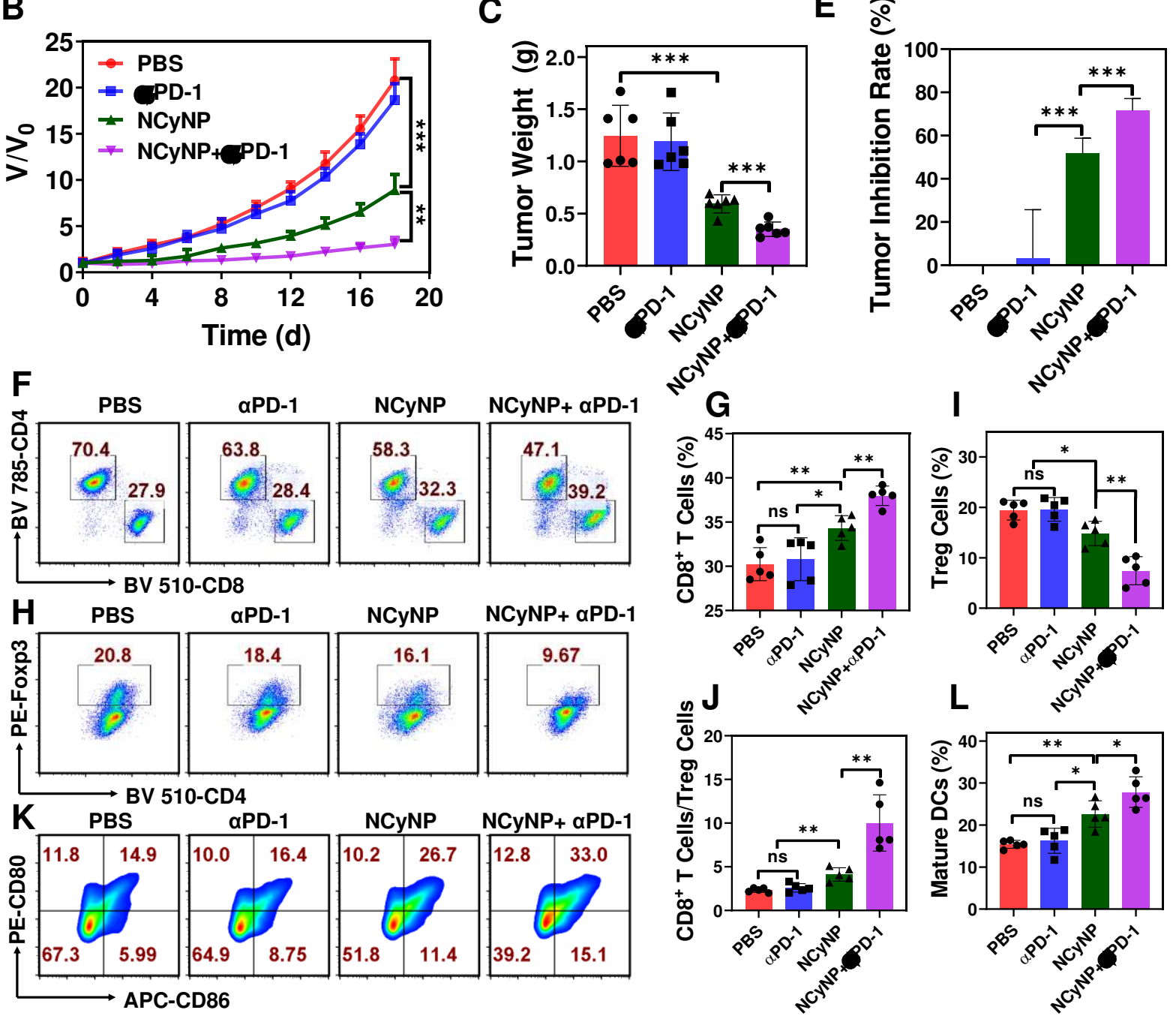

Fig. 5. In vivo antitumor activity of NCyNP plus $\alpha$ PD-1 in a breast tumor-bearing mouse

914 model. (A) Schematic illustration showing in vivo treatment details. (B) Tumor growth curves after

915 treatments with PBS, $\alpha$ PD-1, NCyNP, or NCyNP plus $\alpha$ PD-1. (C) The relative tumor weight of tumors from each group. (D) Tumor images from each group after animals were sacrificed. (E)

Inhibition rates of tumor growth (IRT) in response to different treatments. (F, G) Representative flow cytometry images $(F)$ and corresponding quantification $(G)$ of the percentage of $\mathrm{CD}^{+} \mathrm{T}$ cells in the $\mathrm{CD}_{4} 5^{+} \mathrm{CD}^{+}$tumor infiltrating leukocytes examined by flow cytometry. $(\mathrm{H}, \mathrm{I})$ Representative flow cytometry images $(\mathrm{H})$ and corresponding quantification (I) of the percentage of Treg cells 
$921\left(\mathrm{CD} 5^{+} \mathrm{CD}^{+} \mathrm{CD}^{+}{ }^{+} \mathrm{Foxp}^{+}\right)$in the tumor infiltrating $\mathrm{CD} 4^{+} \mathrm{T}$ cells examined by flow cytometry in 922 tumor tissues at the end of antitumor therapy. (J) Ratio of $\mathrm{CD}^{+} \mathrm{T}$ cells/Treg cells based on FACS 923 analysis. (K, I) Representative flow cytometry images (K) and corresponding quantification (I) of 924 the percentages of mature DCs $\left(\mathrm{CD} 11 \mathrm{c}^{+} \mathrm{CD} 80^{+} \mathrm{CD} 80^{+}\right)$in the $\mathrm{CD} 45^{+}$cells in TDLNs at the end of 925 treatments. Data are presented as the mean \pm SD. Statistical analysis was performed using the 926 Student's t test (ns, nonsignificant. $* P<0.05, * * P<0.01$, and $* * * P<0.001$ ). 

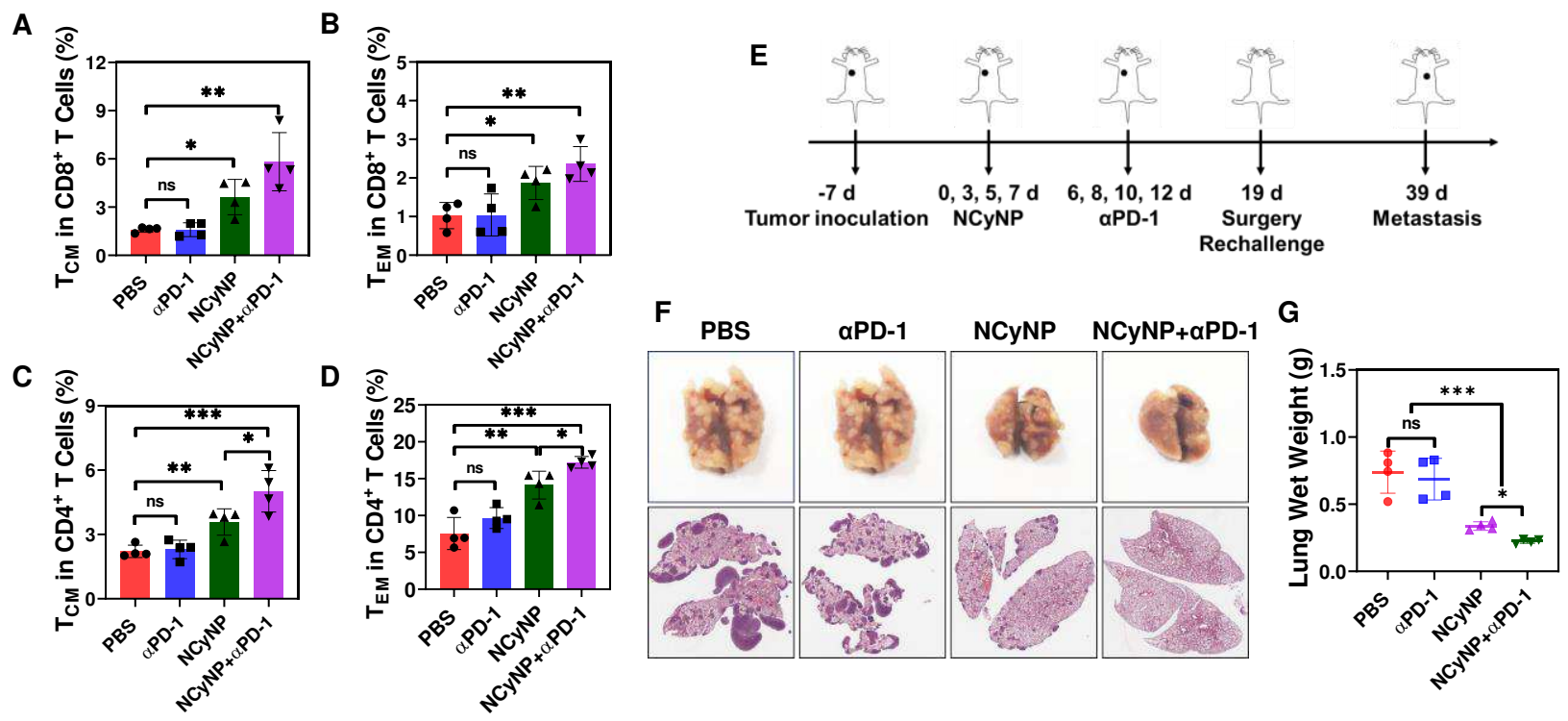

Fig. 6. Metastasis prevention via combination therapy-induced long-term immune

930 memory effects. $(\mathrm{A}, \mathrm{B})$ The proportions of $\mathrm{CD}^{+}$central memory $\mathrm{T}$ cells $\left(\mathrm{CD} 44{ }^{\mathrm{hi}} \mathrm{CD} 62 \mathrm{~L}^{\mathrm{hi}}\right)(\mathrm{A})$

931 and $\mathrm{CD}^{+}$effector memory T cells $\left(\mathrm{CD} 44^{\mathrm{hi}} \mathrm{CD} 62 \mathrm{~L}^{\text {low }}\right)(\mathrm{B})$ in the spleen. $(\mathrm{C}, \mathrm{D})$ The proportions of

$932 \mathrm{CD}^{+}$central memory $\mathrm{T}$ cells $\left(\mathrm{CD} 44^{\mathrm{hi}} \mathrm{CD} 62 \mathrm{~L}^{\mathrm{hi}}\right)(\mathrm{C})$ and $\mathrm{CD}^{+}$effector memory $\mathrm{T}$ cells $933\left(\mathrm{CD} 44^{\text {hi }} \mathrm{CD} 62 \mathrm{~L}^{\text {low }}\right)(\mathrm{D})$ in the spleen. (E) Schematic illustration of NCyNP plus $\alpha \mathrm{PD}-1$ combination 934 therapy to inhibit tumor metastasis. (F) The image shows lung metastatic nodules $20 \mathrm{~d}$ post i.v. 935 infusion of CT26 cells and H\&E staining of lung tissues collected at the end of experiments. (G) 936 The lung wet weight $20 \mathrm{~d}$ post i.v. infusion of CT26 cells. Data are presented as the mean \pm SD. 937 Statistical analysis was performed using the Student's t test (ns, nonsignificant. $* P<0.05$, $* * P<$ $938 \quad 0.01$, and $* * * P<0.001)$. 


\section{Figures}

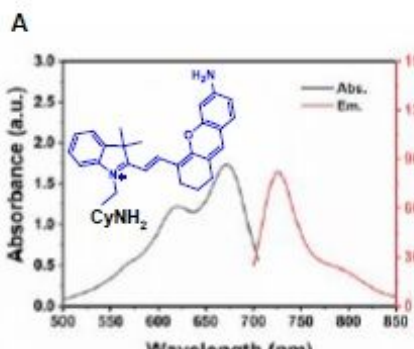

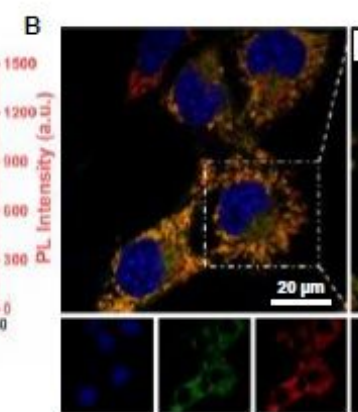

E

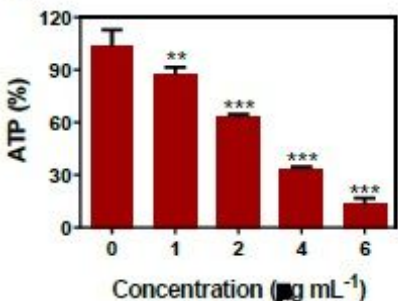

Concentration $\left(\mathrm{g} \mathrm{mL}^{-1}\right)$

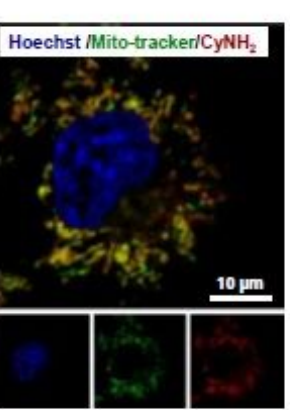

G

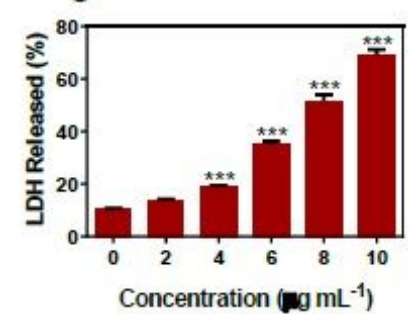

$110 \mathrm{~min}$
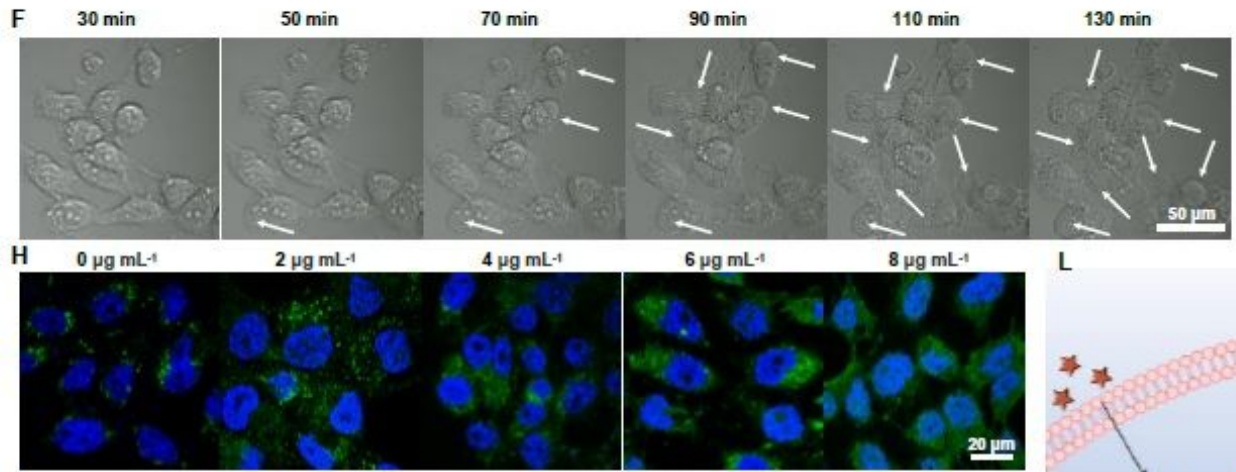

K

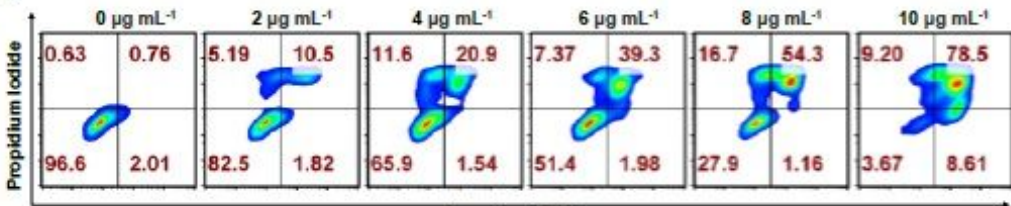

Annexin V-FITC

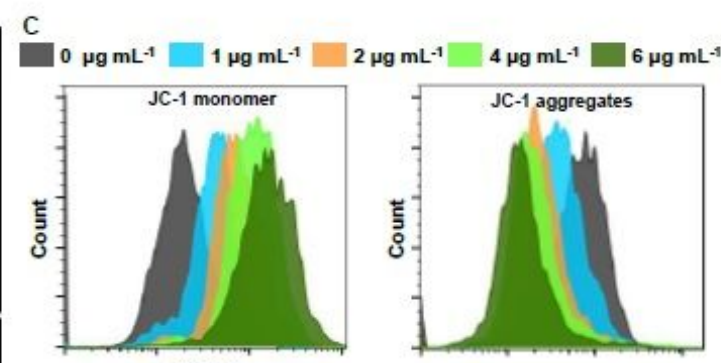

PE-A
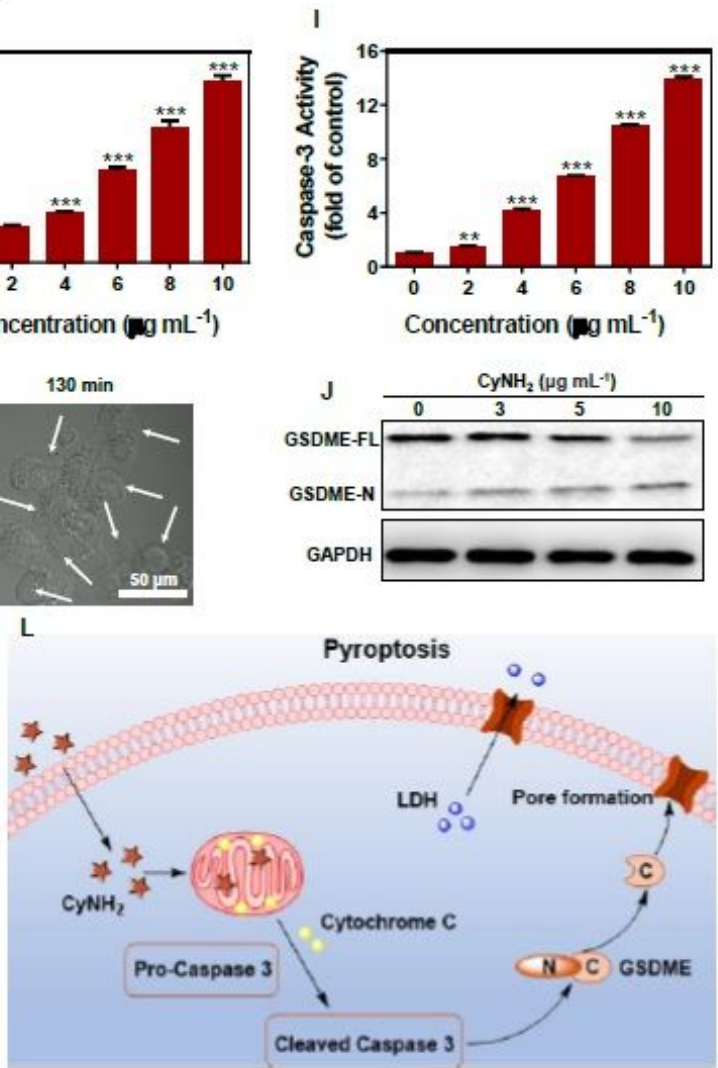

Figure 1

CyNH2 induces cell pyrolysis. (A) The chemical structure, absorption and emission spectra of CyNH2. (B) The intracellular localization of $\mathrm{CyNH} 2$ in $4 \mathrm{~T} 1$ cells. (C) Flow cytometry analysis of changes in mitochondrial membrane potential after incubation with different concentrations of CyNH2. (D, E) The levels of intracellular reactive oxygen species (D) and intracellular ATP (E) after incubation with

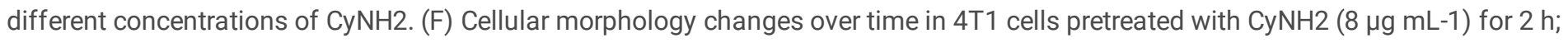
the white arrows indicate pyroptotic cells. (G-J) LDH release (G), intracellular localization of cytoplasmic cyt c (H), intracellular caspase3 activation (I) and western blotting analysis of pyroptosis-related protein expression (GSDME-FL, GSDME-N) (J) in 4T1 cells after treatment with different concentrations of $\mathrm{CyNH2}$. (K) Flow cytometry analysis of apoptosis and necrosis in 4T1 cells 859 treated with different concentrations of $\mathrm{CyNH} 2$. (L) Schematic diagram of the mechanism of CyNH2-induced cell pyrolysis. Data are presented as the mean \pm SD. Statistical analysis was performed using the one-way ANOVA test $\left({ }^{*} P<0.05,{ }^{*} P<0.01\right.$, and $\left.{ }^{* \star *} P<0.001\right)$. 
A
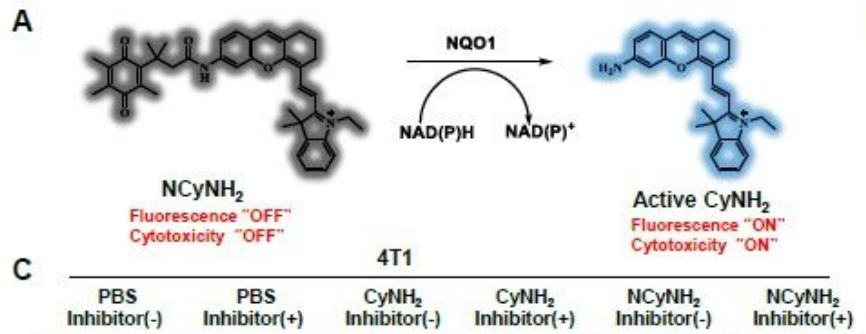

Active $\mathrm{CyNH}_{2}$ ytotoxicity "ON"
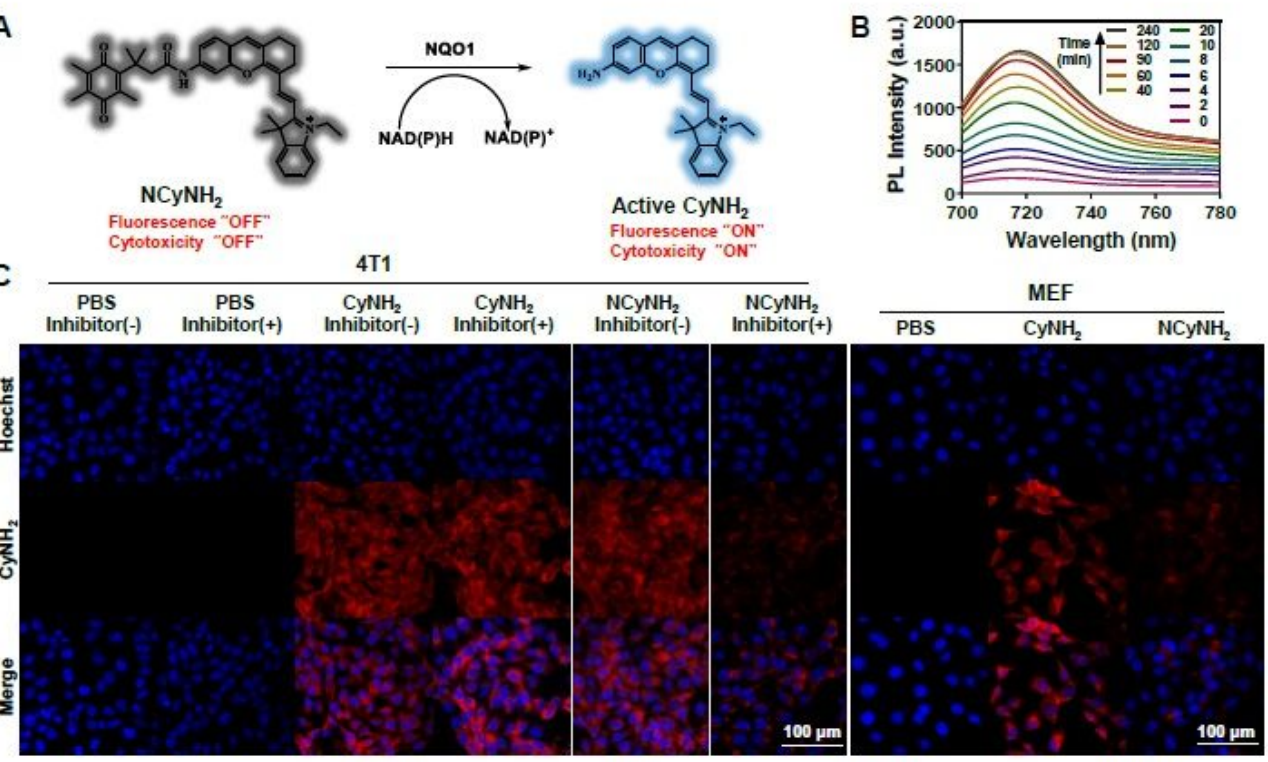

$\mathrm{CyNH}_{2}$ Inhibitor(-)

Inhibitor(+)

D

PBS
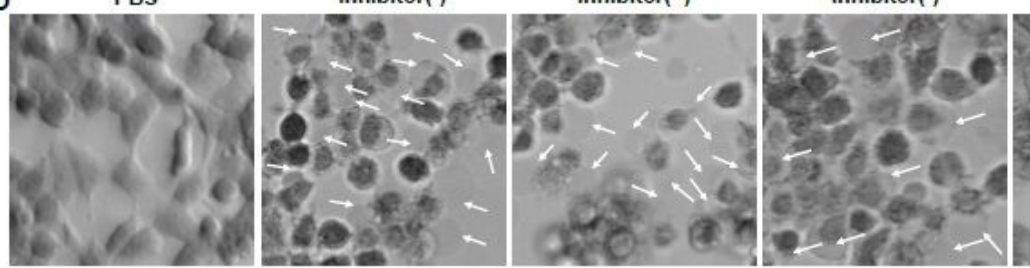

Inhibitor $(+$

E

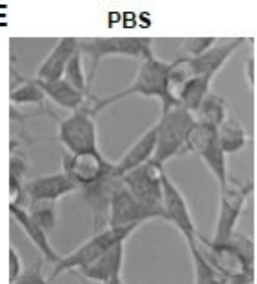

$\mathrm{CyNH}_{2}$
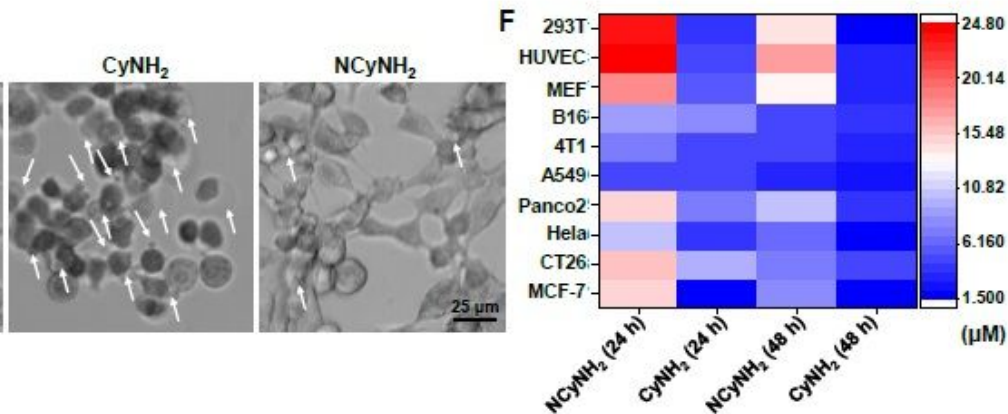

Figure 2

Tumor cell selectivity of NCyNH2. (A) Schematic of intracellular NQ01-triggered cleavage of quinone trimethyl lock moieties of NCyNH2, accompanied by NIR emission turn-on and restored cytotoxicity due to release of $\mathrm{CyNH2}$. (B) Evolution of fluorescence emission spectra $(\lambda e x=670 \mathrm{~nm})$ of NCyNH2 $(2 \mu \mathrm{g} \mathrm{mL}-1)$ upon incubation with NQ01 $(40 \mu \mathrm{g} \mathrm{mL}-1,0.1 \mathrm{mM} \mathrm{NADH}, 0.007 \% \mathrm{BSA} ; \mathrm{pH} 7.4$ PBS, $100 \mathrm{mM} \mathrm{KCl})$ for different lengths of time. (C) Confocal images of $4 \mathrm{~T} 1$ cells and MEFs treated with CyNH2 or NCyNH2 $(1 \mu \mathrm{gL}-1)$ for $24 \mathrm{~h}$ in the absence or presence of ABNCyNH2Active CyNH2Fluorescence "OFF" Cytotoxicity "OFF"Fluorescence "ON" Cytotoxicity

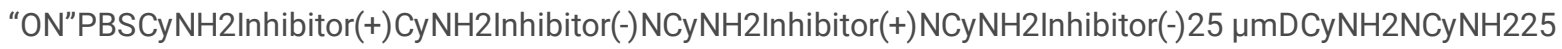
umPBSEFCPBSInhibitor(+) NCyNH2Inhibitor(+)NCyNH2Inhibitor(-)CyNH2Inhibitor(+)CyNH2Inhibitor(-)PBSInhibitor(-) CyNH2HoechstMergeNCyNH2CyNH2PBS4T1MEF100 $\mu \mathrm{m} 100$

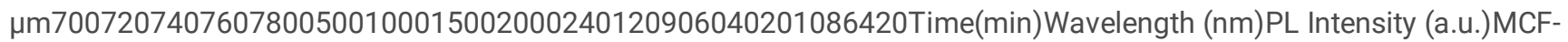

7CT26HelaPanco2A5494T1B16MEFHUVEC293T1.5006.16010.8215.4820.1424.80MEF293THUVECA549B164T1CT26Panco2HelaMCF71.5006.16010.8215.4820.1424.80 $(\mu \mathrm{M})$ an NQ01 inhibitor (50 $\mu \mathrm{M}$ DIC, $1 \mathrm{~h}$ pretreatment). (D) Representative cell morphology of $4 \mathrm{~T} 1$ cells after treatment with CyNH2 or NCyNH2 $(8 \mu \mathrm{g} \mathrm{mL}-1)$ for $8 \mathrm{~h}$ in the absence or presence of an NQO1 inhibitor $(50 \mu \mathrm{M}$ DIC, $1 \mathrm{~h}$ pretreatment). (E) Representative cell morphology of MEFs after treatment with $\mathrm{CyNH} 2$ or NCyNH2 (8 $\mu \mathrm{g} \mathrm{mL}-1)$ for $8 \mathrm{~h}$. (F) Comparison of IC50 values of $\mathrm{CyNH} 2$ and $\mathrm{NCyNH2}$ in different cell lines. 

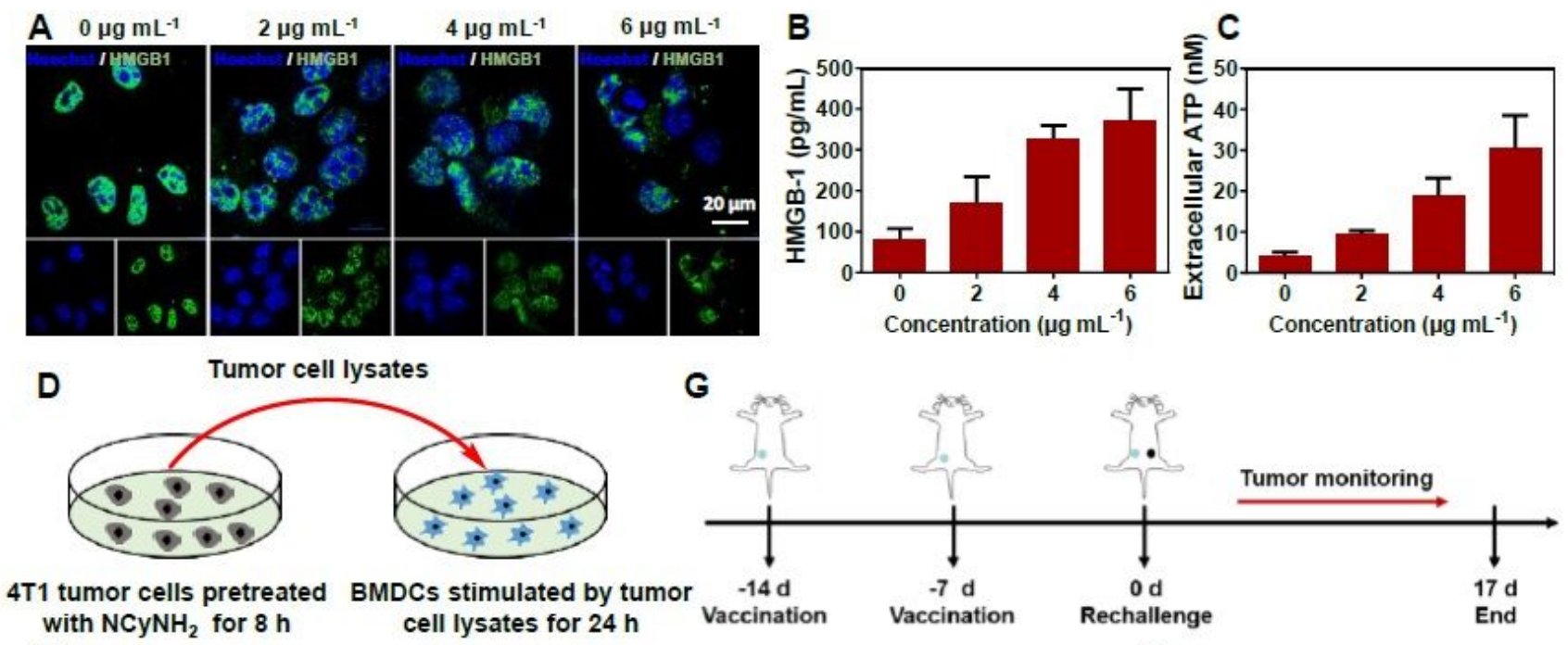

E
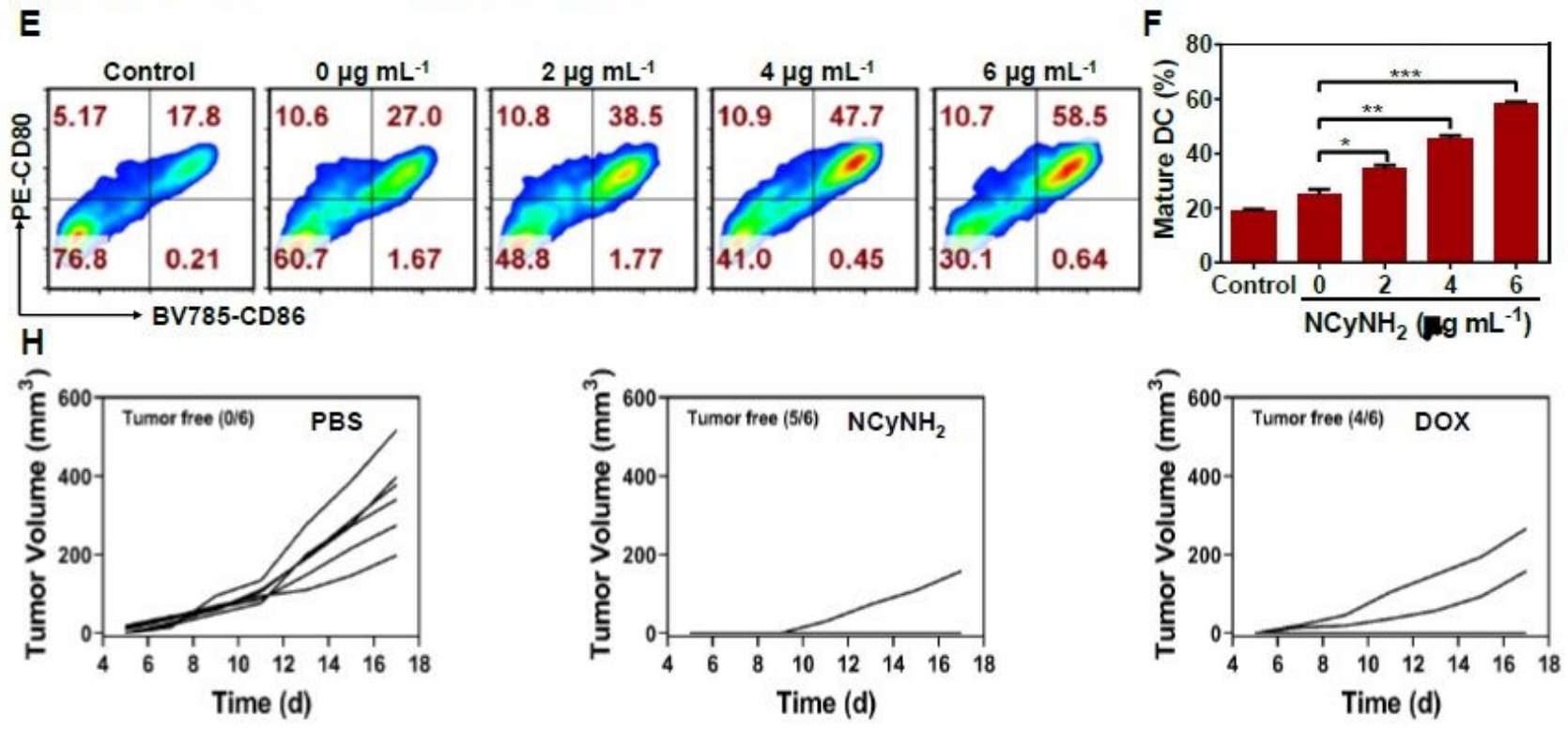

Figure 3

Mature mouse bone marrow-derived dendritic cells (BMDCs) and in vivo prophylactic tumor vaccination study. (A) CLSM examination of HMGB1 release in 4T1 cells after treatment with different concentrations of NCyNH2. Quantitative examination of HMGB1 release (B) and ATP secretion (C) in 4T1 tumor cells after treatment with different concentrations of NCyNH2. (D) Schematics showing the experimental procedure of stimulating BMDCs with cell lysates from cancer cells after being treated with different concentrations of NCyNH2. Representative flow cytometry images $(E)$ and corresponding quantification $(F)$ of mature DCs (CD11C+CD80+CD86+) after stimulation with $4 \mathrm{~T} 1$ cell lysates and treatment with different concentrations of NCyNH2. (G) Vaccination approach in vivo of NCyNH2or DOX-treated dying 4T1 cells incubated subcutaneously at 0 and $7 \mathrm{~d}$, followed by injection of untreated cells in the opposite flank 14 days later. $(H)$ Growth of second tumors after vaccination. Data are presented as the mean \pm SD. Statistical analysis was performed using the one-way ANOVA test $\left({ }^{*} \mathrm{P}<0.05, * * \mathrm{P}<0.01\right.$, and $\left.* \star * \mathrm{P}<0.001\right)$ 


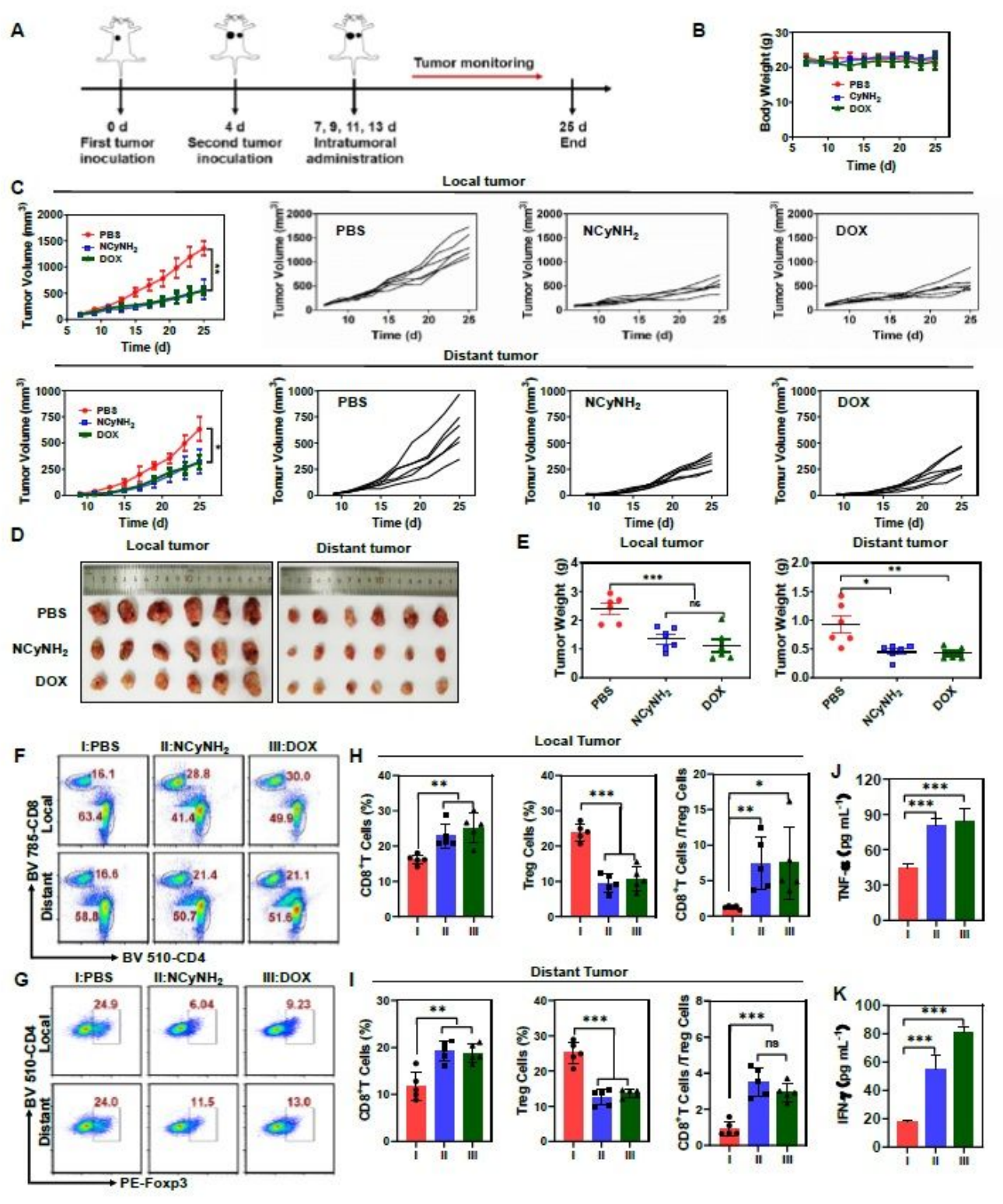

Figure 4

In vivo antitumor effects of localized delivery of NCyNH2 in 4T1 tumor-bearing mice. (A) Schematic illustration of $4 \mathrm{~T} 1$ tumor-bearing mice where only the local tumor (right side) received intratumoral injection (i.t.) of PBS, DOX (3 mg kg-1) or NCyNH2 (2 mg kg-1) four times $(7,9,11,13$ days after tumor implantation). (B) Body weight changes over the course of treatment. (C) Growth curves of local (right side) tumors and distant (left side) tumors in 4T1 tumor-bearing mice with local tumors intratumorally injected with PBS, NCyNH2 or DOX as described in (A). (D, E) Tumor images (D) and relative tumor weights (E) of bilateral tumors (local and distant) isolated from $4 \mathrm{~T} 1$ tumor-bearing mice receiving the treatments indicated in (A). (F) Representative flow cytometry images of CD8+ T cells in CD45+CD3+ tumor-infiltrating leukocytes. (G) Representative flow cytometry images of Treg cells (CD45+CD3+CD4+Foxp3+) in tumorinfiltrating CD4+ $T$ cells in tumor tissues at the end of antitumor therapy. $(\mathrm{H}, \mathrm{I})$ Corresponding quantification of the percentage of $\mathrm{CD} 8+\mathrm{T}$ cells in the CD45+CD3+ tumor infiltrating leukocytes, Treg cells in the tumor infiltrating CD4+ $T$ cells and the ratio of CD8+ T cells/Treg cells based on the analysis of FACS examination in local tumor tissue $(\mathrm{H})$ and distant tumor tissue (I). (J, K) TNF-a (J) and IFN-Y (K) levels in serum after different treatments. Data are presented as the mean \pm SD. Statistical analysis was performed using the Student's $t$ test (ns, nonsignificant. ${ }^{\star} \mathrm{P}<0.05,{ }^{\star *} \mathrm{P}<0.01$, and ${ }^{* \star *} \mathrm{P}<0.001$ ). 


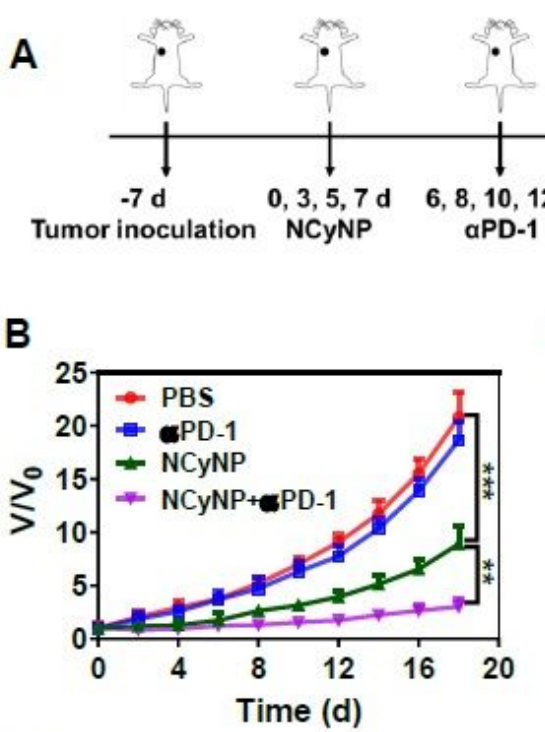

Tumor monitoring
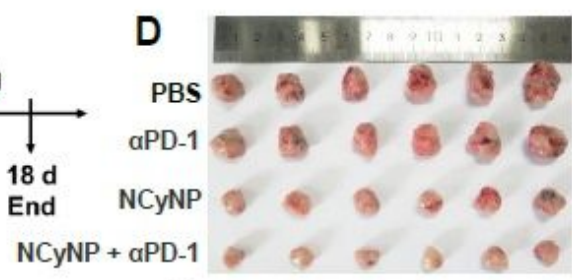

NCyNP + aPD-1

C

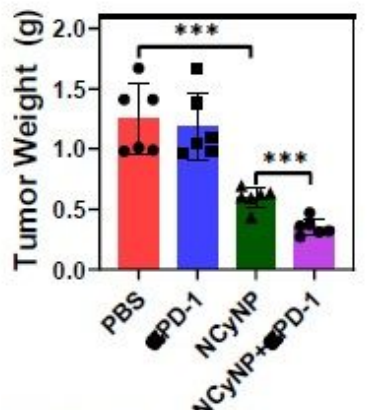

$\mathrm{NCyNP}+\mathrm{aPD}-1$
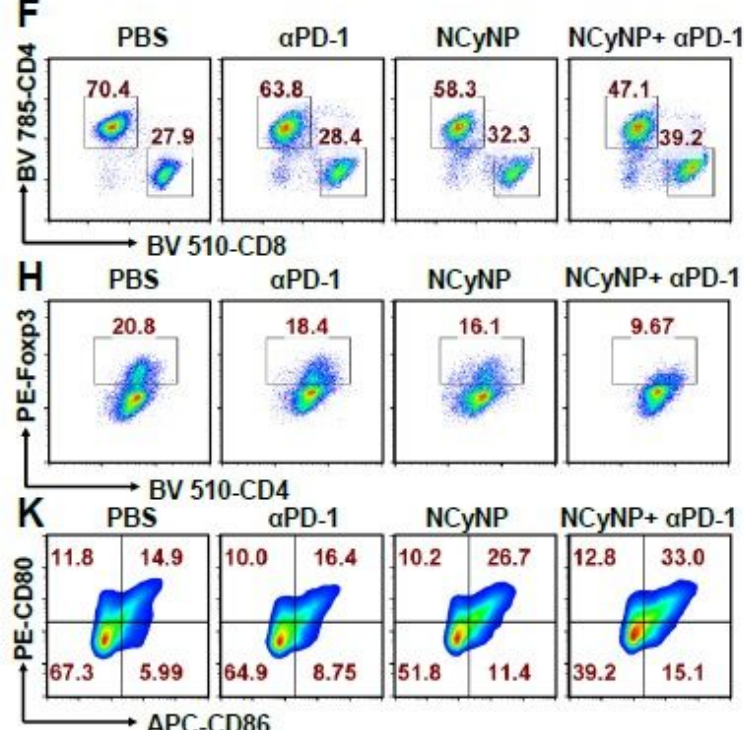

E

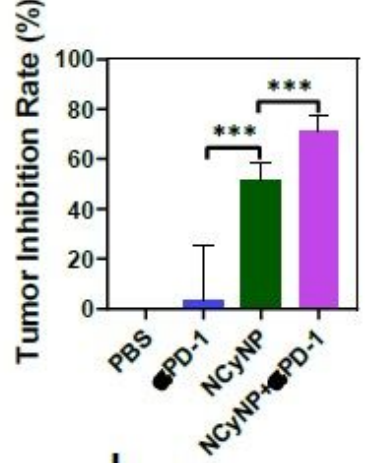

I
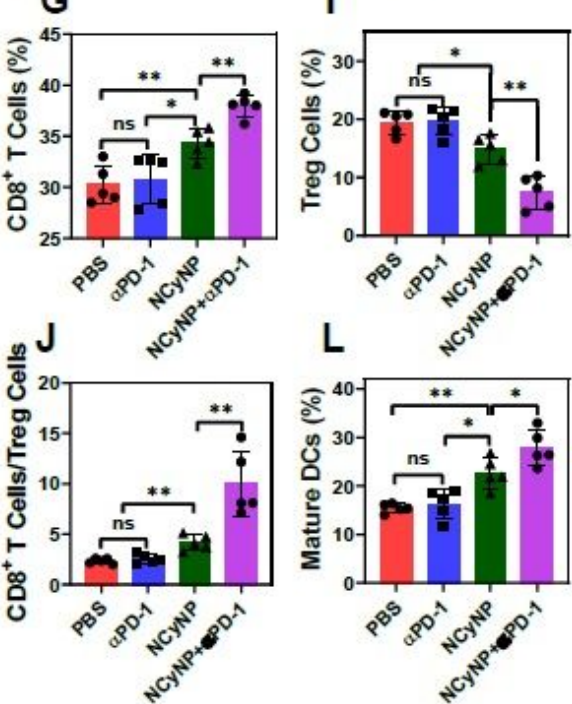

Figure 5

In vivo antitumor activity of NCyNP plus aPD-1 in a breast tumor-bearing mouse model. (A) Schematic illustration showing in vivo treatment details. (B) Tumor growth curves after treatments with PBS, aPD-1, NCyNP, or NCyNP plus aPD-1. (C) The relative tumor weight of 915 tumors from each group. (D) Tumor images from each group after animals were sacrificed. (E) Inhibition rates of tumor growth (IRT) in response to different treatments. $(F, G)$ Representative flow cytometry images (F) and corresponding quantification (G) of the percentage of $\mathrm{CD} 8+\mathrm{T}$ cells in the $\mathrm{CD} 45+\mathrm{CD} 3+$ tumor infiltrating leukocytes examined by flow cytometry. $(\mathrm{H}, \mathrm{I})$ Representative flow cytometry images $(\mathrm{H})$ and corresponding quantification $(\mathrm{I})$ of the percentage of Treg cells $(\mathrm{CD} 45+\mathrm{CD} 3+\mathrm{CD} 4+\mathrm{Foxp} 3+)$ in the tumor infiltrating CD4+ T cells examined by flow cytometry in tumor tissues at the end of antitumor therapy. (J) Ratio of CD8+ T cells/Treg cells based on FACS analysis. (K, I) Representative flow cytometry images $(K)$ and corresponding quantification (I) of the percentages of mature DCs (CD11 c+CD80+CD80+) in the CD45+ cells in TDLNs at the end of treatments. Data are presented as the mean \pm SD. Statistical analysis was performed using the Student's $t$ test (ns, nonsignificant. ${ }^{*} P<0.05, * * P<0.01$, and ${ }^{* \star *} P<0.001$ ). 

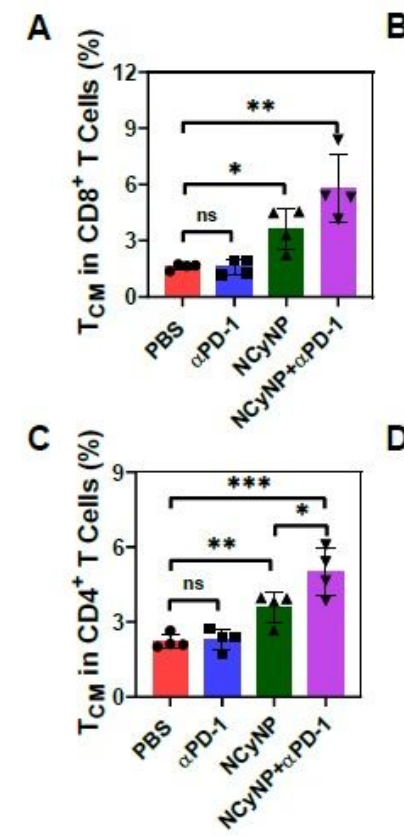

B

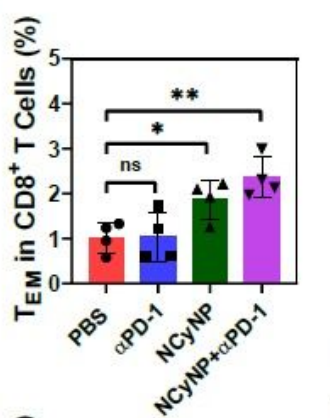

D

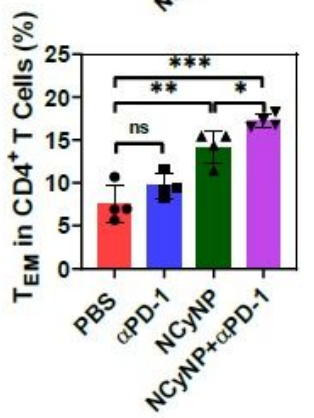

E
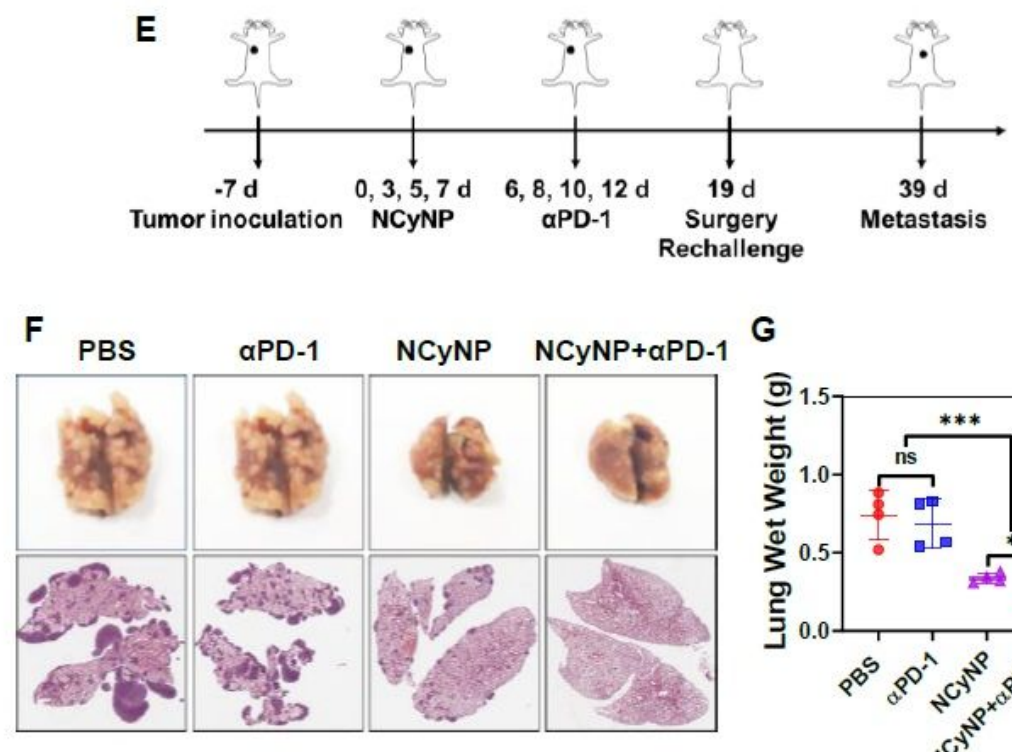

G

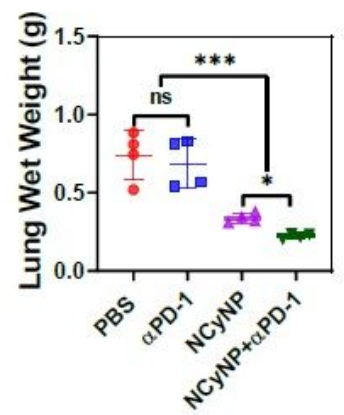

\section{Figure 6}

Metastasis prevention via combination therapy-induced long-term immune memory effects. (A, B) The proportions of CD8+ central memory T cells (CD44hiCD62 Lhi) (A) and CD8+ effector memory T cells (CD44hiCD62 Llow) (B) in the spleen. (C, D) The proportions of CD4+ central memory T cells (CD44hiCD62 Lhi) (C) and CD4+ effector memory T cells (CD44hiCD62 Llow) (D) in the spleen. (E) Schematic illustration of NCyNP plus aPD-1 combination therapy to inhibit tumor metastasis. (F) The image shows lung metastatic nodules $20 \mathrm{~d}$ post i.v. infusion of CT26 cells and H\&E staining of lung tissues collected at the end of experiments. (G)The lung wet weight $20 \mathrm{~d}$ post i.v. infusion of CT26 cells. Data are presented as the mean \pm SD. Statistical analysis was performed using the Student's $\mathrm{t}$ test (ns, nonsignificant. ${ }^{*} \mathrm{P}<0.05,{ }^{*} \mathrm{P}<0.01$, and $* * * P<0.001$ ).

\section{Supplementary Files}

This is a list of supplementary files associated with this preprint. Click to download.

- SupplementaryMaterials.pdf

- movieS1.avi 